\title{
ESTRUTURA DA VEGETAÇÃO ARBÓREA E REGENERAÇÃO NATURAL EM REMANESCENTES DE MATA CILIAR DO RIO MOGI GUAÇÚ - SP.
}

\author{
MARLI JOSÉ PASSOS \\ Engenheiro Florestal
}

Orientador: Prof. Dr. HILTON THADEU ZARATE DO COUTO

Dissertação apresentada à Escola Superior de
Agricultura "Luiz de Queiroz", Universidade de São
Paulo, para obtenção do título de Mestre em
Ciências, Área de Concentração: Ciências
Florestais.

PIRACICABA

Estado de São Paulo - Brasil

Janeiro - 1998 
Dados Internacionais de Catalogação na Pubificaçác (cíp)

DIVISÃO DE BIBLIOTECA E DOCUMENTAÇÁO - Campus "Luiz de OUE UYrOZ"/USP

Passos, Marli José

Estrutura da vegetação arbórea e regeneração natural em remanescentes de mata ciliar do Rio Mogi Guaçú - SP / Marli José Passos. - Piracicaba, 1998.

68 p. : il.

Dissertação (mestrado) - - Escola Superior de Agricultura Luiz de Queiroz, 1998.

Bibliografia.

1. Classificação 2. Composiçāo floristica 3. Diversidade 4. Espécie florestal 5.

Floresta 6. Mata ciliar 7. Regeneração natural 8. Vegetação I. Titulo 
Dedica

M minha filha Maristela, razão do mew excistir.

Ao meus pais Ittor Bbatista Passos (in memmorian) e Arutonia Bernardina Lassos, que me ensinaram o caminho da verdade, horestidade e amor.

Ao mew espasa Reynaldo, por me apoiar em todo a mew trabalho.

Aos meus irmãos Valter, Donizete, Gessileia, Derli, Deuslene e Derice, da qual passei os melhores momentose de minha vida.

Aos meus cunhados, curchadas, sobrichas e sobrichas, que tornaran nossa fumilia mais numerosa e mais felis. 


\section{AGRADECIMENTOS}

À Coordenação de Aperfeiçoamento de Pessoal de Nível Superior (CAPES) pela concep̧̧ão da bolsa de estudos que tornou possível este estudo.

Ao departamento de Ciências Florestais pela oportunidade para a realização desta pesquisa.

Ao Prof. Dr. Hilton Thadeu Zarate do Couto, pela amizade, apoio e orientação em todos os momentos em que necessitei.

Aos amigos e colegas da pós-graduação, que através do convívio diário tornou mais agradável a jornada. Principalmente ao Samir G. Rolim pela auxílio nas análises usadas neste estudo.

Ao Prof. Dr. Ricardo Rodrigues, professor da Escola Superior de Agricultura "Luiz de Queiroz"/USP, pelas sugestões e classificação bôtanica do material coletado.

À Maria Lúcia Kawasaki, pesquisadora do Instituto de Bôtanica, pela classificação das Myrtaceas.

Ao Instituto Florestal por ceder a área em que foi realizado este estudo.

Ao Eng. Agrônomo Dr. Eduardo Amaral Batista e Eng. Florestal Waldir Joel, pesquizadores científicos do Instituto Florestal, pelo apoio nos trabalhos de campo.

Ao Biólogo Dr. Marcos Mecca Pinto, pesquizador científico do Instituto de Botânica.

Aos Srs. Samuel Bamuevo e Paulo Barbosa da Silva (mateiros), funcionários do Instituto de Botânica, pelo apoio na indentificação de campo das espécies.

Ao Sr. Aparecido Alves de Godoy (motorista) e Marcelo de Almeida 
(Vigia) funcionários do Instituto Florestal, equipe de campo de tornaram possível este estudo.

Aos professores do departamento de Ciências Florestais, que contribuíram para o meu crescimento profissional e pessoal.

A todos os funcionários do Departamento de Ciências Florestais, aos funcionários da biblioteca do IPEF e aos funcionários do Laboratório de Métodos Quantitativos. 


\section{SUMÁRIO}

Página

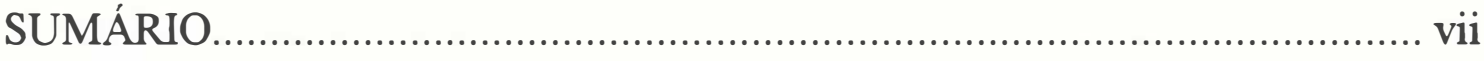

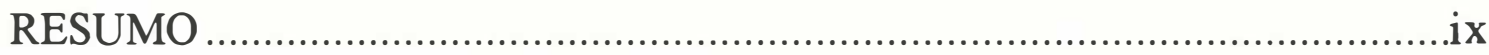

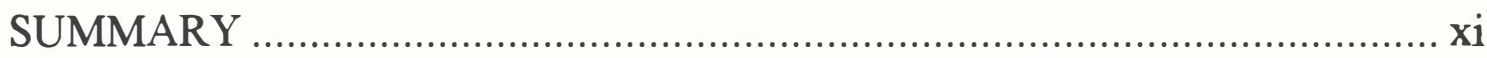

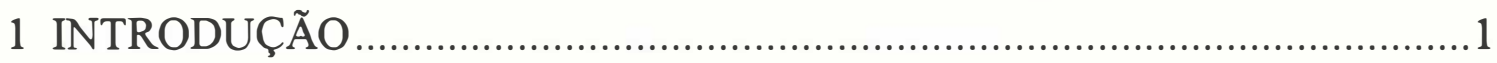

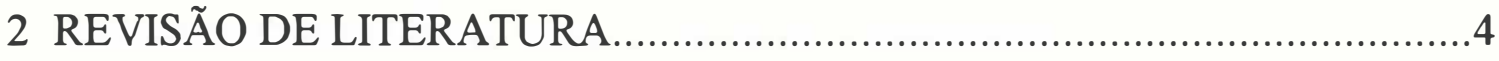

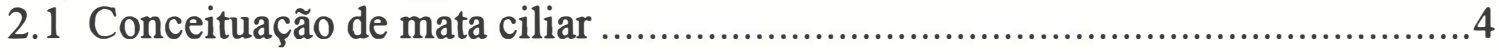

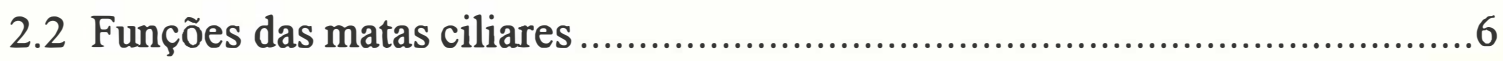

2.3 Estudos sobre a composição florística e a estrutura de matas ciliares .............7

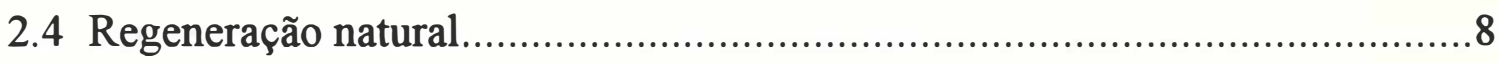

2.4.1 Estudos sobre a regeneração natural em matas ciliares .............................11

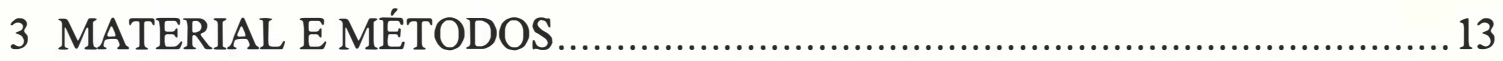

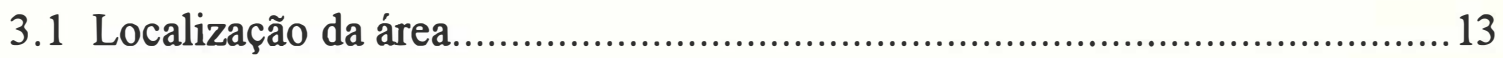

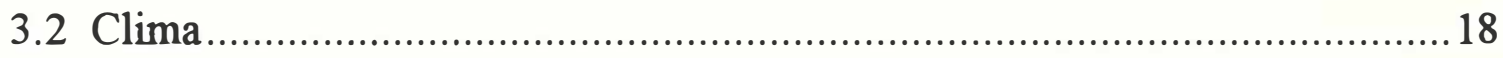

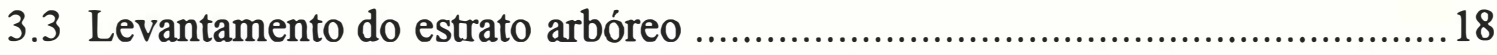

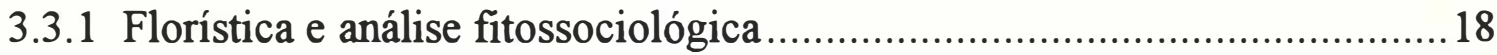

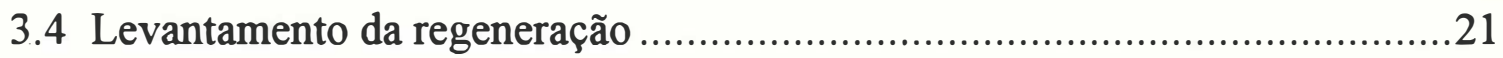

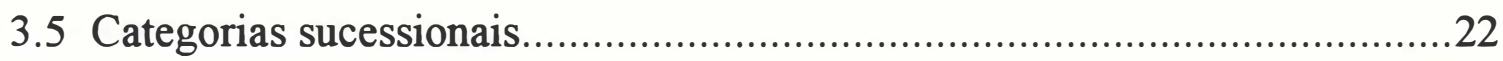

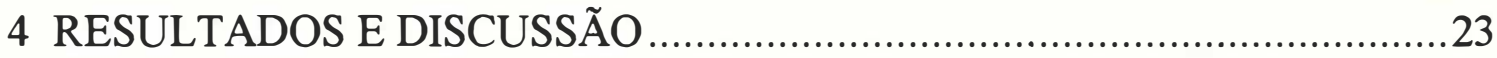

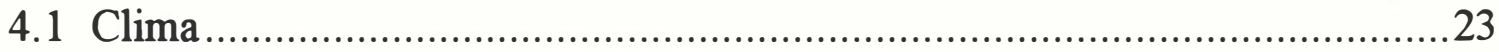

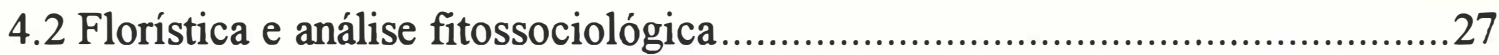

4.2.1 Levantamento geral para as espécies ....................................................30

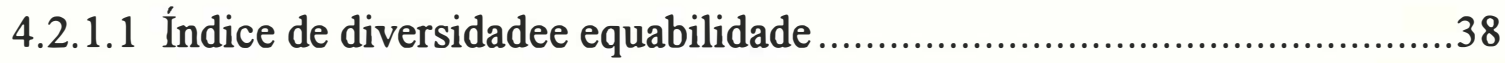

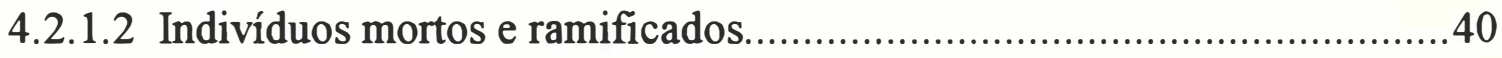

4.2.2 Levantamento geral para as famílias..................................................... 


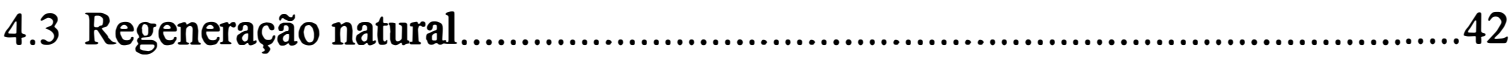

4.3.1 Altura média da regeneração natural por espécie......................................45

4.3.2 Número de indivíduos da regeneração natural por espécie ......................46

4.3.3 Número de espécies da regeneração natural por levantamento .................47

4.2.3.4 Número de indivíduos da regeneração natural por levantamento ...........48

4.3.5 Índice de diversidade para a regeneração natural por levantamento.........49

4.3.6 Número de espécies da regeneração natural por categorias sucessionais. 50

4.3.7 Relações interespecíficas ...............................................................52

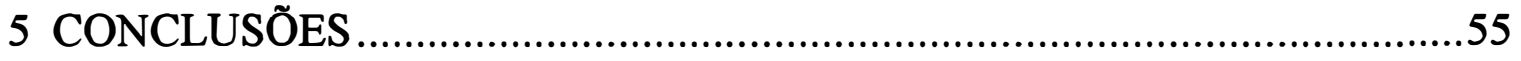

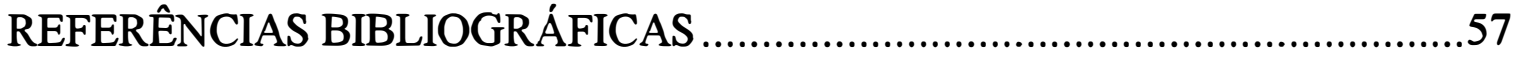

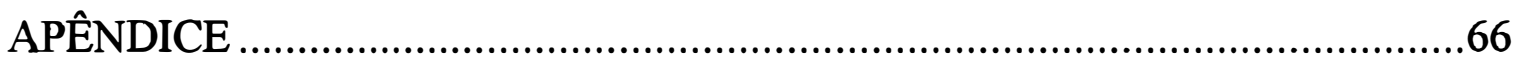




\section{ESTRUTURA DA VEGETAÇÃO ARBÓREA E REGENERAÇÃO NATURAL EM REMANESCENTES DE MATA CILIAR DO RIO MOGI GUAÇÚ - SP.}

Autora: Marli José Passos

Orientador Prof. Dr. Hilton Thadeu Zarate do Couto

\section{RESUMO}

No presente estudo, foi realizado o levantamento fitossociológico do estrato arbóreo e a análise da regeneração natural em remanescentes de mata ciliar da Estação Ecológica de Mogi Guaçú, no município de Mogi Guaçú-SP. Utilizou-se o procedimento de amostragem aleatória, locando-se 10 parcelas amostrais de 300 $\mathrm{m}^{2}(10 \mathrm{~m} \times 30 \mathrm{~m})$ para o estrato arbóreo e 20 subparcelas de $1 \mathrm{~m}^{2}(1 \mathrm{~m} \times 1 \mathrm{~m})$ que foram locadas sistematicamente dentro de cada parcela amostral para 0 levantamento da regeneração natural. Foram medidos todos os indivíduos arbóreos maiores que $15,70 \mathrm{~cm}$ de CAP nas parcelas e todos os indivíduos menores que $15,70 \mathrm{~cm}$ de CAP nas subparcelas. Para a regeneração, as medições se iniciaram em outubro de 1995 e finalizaram-se em outubro de 1996, sendo realizadas a cada seis meses, totalizando, dessa maneira, três medições.

Para o estrato arbóreo, foram encontrados 349 indivíduos de 43 espécies e 21 famílias. As famílias que apresentaram maior riqueza em espécie foram as Euphorbiaceae, Fabaceae, Myrtaceae, Lauraceae e Mimosaceae. A densidade total encontrada foi 1163 indivíduos/hectare, apresentando uma área basal de 25,22 $\mathrm{m}^{2}$ para os indivíduos amostrados. O diâmetro médio encontrado foi $14,65 \mathrm{~cm}$ e a altura média estimada em 8,26 m. O índice de diversidade foi 3,07, e a equabilidade de 0,82, o número de indivíduos mortos foi de $8,60 \%$ e o número de indivíduos ramificados, $4,30 \%$. 
Pelos parâmetros fitossociológicos, as espécies Sebastiana klotzchiana, Miconia langsdorfii, Gallesia integrifolia, Alchornea glandulosa e Eugenia sp apresentaram maior valor de importância. As familias com maior valor de importância foram Euphorbiaceae, Melastomataceae, Myrtaceae, Mimosaceae e Lauraceae.

Para a regeneração natural, foram encontrados 77 indivíduos de 20 espécies. $\mathrm{O}$ índice de diversidade foi de 2,57, e a equabilidade, 0,89, para o primeiro levantamento. No segundo levantamento foram contabilizados 105 indivíduos de 21 espécies, apresentando índice de diversidade de 2,62 e equabilidade de 0,87. Para 0 terceiro levantamento, foram encontrados 129 indivíduos de 22 espécies, com índice de diversidade de 2,56 e equabilidade de 0,85 .

As espécies que apresentaram maiores crescimentos em altura foram Gallesia integrifolia, Miconia langsdorfii e Duguetia lanceolata. A espécie mais abundante no primeiro e segundo levantamentos foi Eugenia sp e a espécie Machaerium brasiliensis apresentou número crescente de indivíduos do primeiro para o terceiro levantamento. As espécies Guarea guidonea e Cyclolobium vecchi apresentaram decréscimo na altura média do primeiro para o segundo levantamento e Gallesia integrifolia, Miconia langsdorfii e Casearia sylvestris não apresentaram crescimento durante o período de observação. Alchornea glandulosa apresentou redução do número de indivíduos.

Todas as espécies amostradas no estrato arbóreo também foram amostradas na regeneração. As espécies de final de sucessão se apresentaram em maior número, indicando que a mata em estudo se apresenta em dinâmica de sucessão natural.

Foi encontrada, ainda, correlação positiva significativa entre o número de indivíduos da regeneração com o estrato arbóreo. 


\title{
STRUCTURE OF THE ARBOREAL VEGETATION AND NATURAL REGENERATION IN REMAINDERS OF GALLERY FOREST OF THE RIVER MOGI GUAÇÚ - SP.
}

\author{
Author: MARLI JOSÉ PASSOS \\ Adviser: Prof. HILTON THADEU ZARATE DO COUTO
}

\section{SUMMARY}

In this study it was surveyed the phytosociologie caractheristics of the arboreal stratum and natural regeneration in remainders of the gallery forest of Mogi Guaçú Ecological Station, in Mogi Guaçú county. A procedure of random sampling was used, being allocated 10 sample plots of $300 \mathrm{~m}^{2}(10 \mathrm{~m} \mathrm{x} 30 \mathrm{~m})$ for the arboreal stratum and 20 sub-plots of $1 \mathrm{~m}^{2}(1 \mathrm{~m} \mathrm{x} 1 \mathrm{~m})$ that was selected systematically inside of each plot for surveying of the natural regeneration. All arboreal individuals larger than $15,70 \mathrm{~cm}$ of Girth at breast hosylt (GBH) in the plots and all individuals smaller than $15,70 \mathrm{~cm}$ of GBH in the plots we measured. The mensurements of the natural regeneration were done in October of 1995 to October of 1996, being accomplished each six months, totalizing three mensurations.

For the arboreal stratum, 349 individuals of 43 species and 21 families were found. The families that presented the larger richness were Euphorbiaceae, Fabaceae, Myrtaceae, Lauraceae and Mimosaceae. The total density was 1163 individuals/ha. It was found a basal area of $25,22 \mathrm{~m}^{2}$ per hectere for the sampled plots. The average DBH was $14,65 \mathrm{~cm}$ and the estimated average height $8,26 \mathrm{~m}$. The diversity index (Shannon) was 3,07, the number of dead individuals was $8,60 \%$ and the number of forkes individuals was $4,30 \%$. 
The species Sebastiana klotzchiana, Miconia langsdorfii, Gallesia integrifolia, Alchornea glandulosa and Eugenia sp were considered the must important. The most important families were Euphorbiaceae, Melastomataceae, Myrtaceae, Mimosaceae and Lauraceae.

Natural regeneration surveyed, showed 77 individuals of 19 species, 105 individuals of 18 species and 129 individuals of 18 species for the first, second and third surveys, respectively.

The species that presented larger growths in height were: Gallesia integrifolia, Miconia langsdorfii and Duguetia lanceolata. The most abundant species in the first, second and third surveys was Eugenia, the species Machaerium brasiliensis presented growing number of individuals form the first to the third survey. The species Guarea guidonea and Cyclolobium vecchi presented descend of the first for the second survey and Gallesia integrifolia, Miconia langsdorfii and Casearia sylvestris they didn't present growth during the observation period. Alchornea glandulosa presented reduction of the number of individuals.

All the species sampled in the arboreal stratum were also sampled in the regeneration survey. The species of the end of sucession came in larger number, indicating that the forest in study comes in dinamics of natural sucession.

It was found significant positive correlacion among the number of individuals of the regeneration with nome caracteristics of the arboreal stratum. 


\section{INTRODUÇÃO}

Os ecossistemas tropicais são altamente diversificados biologicamente, como foi verificado por diversos autores como Hueck (1972), Bertoni et al. (1982), Leitão Filho (1982), Mantovani (1993), entre outros.

O Brasilé o país que possui a maior porção de matas tropicais do planeta, com cerca de 300 milhões de hectares, ou seja, um terço do total mundial ainda remanescente. Detém, em razão disso, a maior diversidade genética dentre todos os países, com plantas superiores cientificamente conhecidas (Carvalho, 1990).

No Estado de São Paulo, a vegetação natural tem sofrido os mais diversos tipos de agressões, devido à facilidade de acesso, às pressões agropecuárias e imobiliárias e a incêndios acidentais e criminosos, restando, dessa devastação, apenas fragmentos de florestas naturais, que já não são suficientes para preservar a diversidade original (Fonseca, 1981). Como se não bastasse a perda desta diversidade, chegou-se à conclusão de que conhecemos mais a floresta amazônica do que os ecossistemas paulistas (Mantovani, 1993).

Os ecossistemas florestais que cobriam mais de $80 \%$ da superfície do Estado de São Paulo desde o início de seu processo de desenvolvimento foram reduzidos, drasticamente, a menos de 5\% da área do Estado (CONSEMA, 1985). Nessa estimativa, estão incluídas as matas do interior paulista, englobando as matas ciliares as quais não foram poupadas do processo de fragmentação e das conseqüências desse processo, que, de acordo com Viana (1990), são as seguintes: 
diminuição da diversidade biológica, distúrbio no regime hidrológico de bacias hidrográficas, mudanças climáticas e deterioração da qualidade de vida das populações tradicionais .

Leitão Filho (1989) relata que diversos fatores afetam as características florísticas das matas ciliares, tais como: extensão e largura dos cursos d'água, variação no período de inundação, topografia das margens, características florísticas da vegetação circundante e fatores de clima e solo.

Embora sejam extremamente complexas a preservação e a recuperação dos fragmentos florestais remanescentes, deve-se buscar sempre este objetivo, pois estes fragmentos constituem fonte de biodiversidade, oferecem abrigos à fauna, lazer e educação.

Para que se possam recuperar e manejar adequadamente os recursos florestais, faz-se necessário conhecer diversos fatores para se poder entender melhor a dinâmica de populações de plantas que, segundo Harper (1977) e Solbrig (1980), citados por Mantovani (1993), seriam: a quantidade de propágulos dispersos ou a chuva de sementes; o banco de sementes do solo; o recrutamento da população de plântulas; os efeitos da densidade, de predadores, e da sazonalidade; a capacidade reprodutiva e de crescimento; o ciclo de vida e os períodos reprodutivos, a estrutura da comunidade e a diversidade.

O presente estudo, então, pelo que ficou exposto, além de ser um complemento dos estudos realizados anteriormente,. Tem como objetivos, em relação à mata ciliar da região de Mogi Guaçú:

- Analisar a composição florística e a estrutura de um remanescente de mata ciliar na região de Mogi Guaçú;

- Classificar as espécies arbóreas quanto aos seus respectivos grupos ecológicos;

- Avaliar a diversidade e a similaridade dessa mata com as 
características de outras semelhantes ao do estudo;

- Avaliar a composição florística, diversidade e a abundância da regeneração natural.

- Correlacionar a vegetação do estrato arbustivo-arbóreo com a regeneração natural. 


\section{REVISÃO BIBLIOGRÁFICA}

\subsection{Conceituação de mata ciliar}

O conceito de mata ciliar pode ser entendido como a formação florestal ocorrente ao longo dos cursos d'água, em locais sujeitos a inundações temporárias, em nascentes e olhos d'água.

Diversos fatores atuando de forma conjunta, de maneira e com importância distintas no tempo, criam condições ambientais muito diversas para a ocorrência de matas que ladeiam os cursos d'água, o que acarreta variações estruturais e florísticas altamente distintas. Devido a estes fatores, existem na literatura vários termos correlatos, os quais tentam associar as variações regionais e os fatores ambientais com a vegetação (Bertoni et al., 1982).

Ab'Saber (1971) associa as florestas de galeria ao cerrado, como elementos típicos da paisagem dos planaltos tropicais do centro-oeste do Brasil. As florestas de galeria teriam sofrido interferência dos grandes maciços florestais como mata amazônica, atlântica e as matas do rio Paraná e desenvolveram-se no domínio do cerrado, acompanhando a rede de drenagem.

Mantovani (1989), fazendo uma revisão dos termos utilizados para denominar as florestas relacionadas a cursos fluviais no Brasil, encontrou para as planícies das regiões amazônica e centro-oeste, o termo "mata ciliar", onde os grandes rios correm entre diques marginais, formados por deposição de 
sedimentos, e por trás dos quais há várzeas extensas, formando verdadeiras pestanas dos rios. Já para a floresta mesofítica de qualquer grau de deciduidade, que orla um ou os dois lados de um curso de água em uma região onde a vegetação do interflúvio não é floresta contínua dá-se o nome de "mata de galeria".

Segundo o mesmo autor, no Rio Grande do Sul, a mata ciliar foi denominada "mata de fecho" ou de "anteparo", por formar verdadeiras cercas vivas ou anteparos entre os cursos de água e os campos sulinos. Já a "Floresta de condensação" se refere às matas situadas em fundos de vale com condensação de neblina. A "Mata aluvial", é uma floresta situada sobre solos aluviais que quando se encontra sobre aluviões antigos ou em várzeas aluviais é designada "floresta paludosa".

Lima (1989) caracteriza "área ripária como a porção do terreno que inclui a ribanceira do rio propriamente dito e a planície de inundação, com suas condições edáficas próprias e a vegetação que aí ocorre (a mata ciliar ou ripária). O conjunto, ou seja, a área, a mata e a vegetação associada, o piso florestal e as interações com o meio, poderiam ser chamados de ecossistema ripário".

Catharino (1989) propõe o termo "mata ripária" por considerá-lo mais adequado a associações vegetais que ocorrem ao longo dos cursos d'água.

Rodrigues (1991) recomenda que a mata ou a floresta ripária tenha seu uso restrito à faixa de vegetação sob a interferência direta da presença de água, sob condições peculiares de solo e com vegetação característica. Exclui desse conceito as matas de brejo.

O termo mata ciliar é o mais empregado no meio científico, nos principais meios de comunicação e na própria legislação, referindo-se à vegetação ao longo e ao redor dos corpos d'água (nascentes, rios, lagos ou reservatórios ), seja se tratando de floresta natural, seja plantada. No decorrer deste trabalho, 
emprega-se o termo genérico mata ciliar independente da largura do rio, origem do solo em que se encontra, do local onde está localizado, de como são formados ou do grau de influência da água do rio sobre a vegetação.

\subsection{Funções das matas ciliares}

A mata ciliar é de vital importância para a proteção dos mananciais. Estudos têm demostrado que uma faixa de mata ciliar diminui o escoamento subsuperficial dos fluxos de água para os canais (Lima, 1989).

A vegetação ciliar proporciona maior estabilidade das margens causada pelo emaranhado radicular (Steinblus et al., 1984) que impede a erosão acelerada e o solapamento dos barrancos, eventos fatais para um rio que diminuem a vazão do leito pelo assoreamento e, em conseqüência, provocam enchentes e alterações na vida aquática (Marques et al.,1961).

A faixa ciliar é responsável pelo controle de menores concentrações de sedimentos no deflúvio e pela incorporação destes sedimentos e de produtos químicos aos cursos d'água. Este controle se deve principalmente ao emaranhado das raízes (para sedimentos) e à atuação de microrganismos do solo, à absorção pelas raízes da vegetação e à retenção nos colóides da zona saturada do solo e da matéria orgânica (no caso de nutrientes), funcionando, dessa maneira, como "sistemas tampão" (do inglês "buffer strips" - Pesterjohn \& Correl, 1984; Lima, 1989).

A diminuição das flutuações térmicas dos cursos d'água também é atribuída à vegetação ciliar, que funciona como interceptadora e filtradora da maior parte da radiação solar, fazendo com que a porção dos raios solares que chega até a água seja constante. Burton \& Likens (1973) mostraram que a retirada da vegetação ripária em pequenos rios densamente sombreados pode causar um 
aumento na temperatura das águas.

No caso dos ecossistemas aquáticos, a mata ciliar mantém as condições adequadas para a sobrevivência e reprodução da ictiofauna, fornecendo alimentos como sementes, frutos e matéria orgânica vegetal, proporcionando sombreamento e abrigos naturais para a fauna aquática (Lima, 1989).

Para a fauna terrestre, os ecossistemas ripários servem como local de abrigo, reprodução, alimentação e para saciar a sede (Fonseca \& Redford, 1984), principalmente em áreas onde a vizinhança se constitui de campos e cerrados, e onde os recursos necessários para a sobrevivência da fauna são escassos. Assim, as matas ciliares são os habitats nos quais se encontram a maior riqueza e diversidade de espécies de mamíferos (Marinho Filho \& Reis, 1989) e outras espécies de animais.

Outro papel importante exercido pela mata ciliar, seria de corredores para a migração de animais e favorecimento do fluxo gênico, tanto para outras matas ciliares como para outros tipos de vegetação adjacentes que sofreram fragmentação (Marinho Filho \& Reis, 1989; Mantovani, 1989).

\subsection{Estudos sobre a composição florística e a estrutura de matas ciliares.}

Os primeiros estudos enfocando a flora do Estado de São Paulo foram realizados no final do século passado e no início deste, quando viajantesnaturalistas fizeram uma descrição da flora encontrada durante as expedições que enfocavam as principais formações vegetais e a flora dos principais rios paulistas como Grande, Tietê, do Peixe, Aguapeí e Paranapanema. Encontram-se também, na literatura, descrições dos manguezais de Santos e da flora de ilhas do litoral paulista. Entretanto, essas descrições tinham caráter fitogeográfico ou fitofísionômico, sem a caracterização da flora das matas ciliares (Catharino, 
1989).

Somente a partir da década de 70 começaram a surgir os primeiros trabalhos sobre estudos florísticos e fitossociológicos da vegetação ripária e das vegetações anexas no Estado de São Paulo. Dentre esses trabalhos, aquele considerado um marco da aplicação de métodos fitossociológicos em formação florestal no Estado de São Paulo foi o realizado por Gibbs \& Leitão Filho (1978), em que foi avaliada a estrutura de uma floresta de galeria, no município de Mogi Guaçú.

A partir da década de 80, ocorreu uma grande divulgação dos estudos de florística e fitossociologia em todos os tipos de vegetação. Estes estudos são apresentados por Gibbs \& Leitão Filho (1980); Bertoni (1984); Mantovani \& Catharino (1985); Durigam \& Garrido (1988); Gianotti (1988); Mantovani et al. (1989); Rodrigues (1991); Mencacci \& Schittler (1992); Rozza \& Ribeiro (1992); Zipparro \& Schlittler (1992); Leitão et al. (1994); Sanchez et al. (1995) e Bernacci et al. (1995).

Como foi relatado, os trabalhos fitossociológicos em matas ciliares se tornaram mais abundantes nas últimas décadas, trazendo grande contribuição para o mundo científico. Mas a preocupação em caracterizar os ambientes de amostragem, fazendo correlações entre o ambiente físico, a vegetação e a sucessão vegetal ainda está começando a dar os primeiros passos na busca de ampliar mais os conhecimentos das espécies que ocorrem em qualquer mata ciliar.

\subsection{Regeneração natural}

Crocker (1938) afirma que a vegetação de um local é formada por um componente real (indivíduos presente no local) e um componente potencial (sementes e propágulos existentes no solo). Argumenta, ainda, que esse banco de 
sementes é constituído por espécies representantes da vegetação atual, de etapas sucessionais anteriores e espécies que não tinham estado presentes na área e que fazem parte do potencial florístico devido à sua capacidade de dispersão.

Segundo Silva Filho (1991), o estudo da dinâmica dos estados sucessionais da vegetação, dentro da regeneração das florestas tropicais, constituise num ponto de relevância para a recomposição e manejo de qualquer formação vegetal.

Petit (1969) indica a necessidade de um estudo aprofundado da regeneração natural na elaboração de planos de manejo florestal, pois ele apresenta informações importantes que normalizarão as intervenções no povoamento de uma floresta.

Finol (1975), afirma que a regeneração natural é uma fase importante para a sobrevivência, desenvolvimento e manutenção do ecossistema florestal.

Aubreville (1938) se refere ao caráter dinâmico das florestas tropicais, como manchas florestais com estrutura e composição florística distintas, que formam um mosaico em processo contínuo de modificação ao longo do tempo.

Através de estudos desenvolvidos em florestas temperadas, Watt (1947) propôs um modelo de regeneração da floresta, considerando o caráter cíclico das manchas florestais entendidas como as fases sucessionais distintas. $\mathrm{O}$ conjunto destas fases representa o mosaico observado por Aubreville (1938), o qual, ainda, mostrou que as florestas apresentam três fases de desenvolvimento: fase de clareira, fase de construção e fase de madura.

O primeiro autor a adaptar o modelo de mosaico sucessional proposto por Watt (1947) para a floresta tropical foi Whitmore (1975). Outros trabalhos foram desenvolvidos em florestas tropicais, em diferentes regiões, que vieram contribuir para o entendimento sobre a dinâmica florestal, da qual destacamos os trabalhos de Budowski (1965), Oldeman (1989), Denslow (1980), Brokaw (1987) 
e Martinez-Ramos (1985).

$\mathrm{Na}$ sucessão vegetal, diferentes grupos de espécies requerem recursos ambientais distintos para o crescimento, desenvolvimento e reprodução. Dessa maneira, as espécies de plantas tropicais têm sido classificadas de diversas formas em relação ao seu comportamento na dinâmica de sucessão. Budowski (1965) dividiu o processo de sucessão secundária, em florestas tropicais americanas, em quatro fases denominadas como pioneiras, secundárias iniciais, secundárias tardias e clímax. Whitmore (1978), reconhece quatro grupos de espécies: a) espécies que se estabelecem e crescem sob dossel fechado; b) as que se beneficiam quando ocorre a abertura do dossel; c) as que requerem o dossel aberto para crescer e reproduzir e d) as que se estabelecem, crescem e reproduzem somente em dossel aberto. Denslow (1980) classifica os grupos ecológicos como: a) espécies de clareiras grandes; b) espécies de clareiras pequenas e c) espécies tolerantes. Whitmore (1982) cita apenas dois grupos: intolerantes à sombra e tolerantes à sombra. Martinez-Ramos (1985) classifico como pioneiras, nômades e tolerantes.

Gomez-Pompa (1971) salienta que as espécies apresentam uma ampla variedade de respostas, que seria o continuum de adaptação à luz, nos diferentes estádios de desenvolvimento. Bazzaz e Pichett (1980), consideram que as diferenças entre as espécies adaptadas ao sol ou à sombra não são claras em florestas tropicais.

Devido, pois, à falta de uma caracterização clara e devido, também, as peculiaridades das espécies florestais tropicais para a definição dos grupos ecológicos, dificulta-se o entendimento, a classificação, a interpretação e a comparação de resultados de diferentes estudos.

Assim como o termo "mata ciliar", o termo "regeneração natural" também tem uma metodologia de avaliação muito ampla. Para Finol (1971), todos 
os descendentes das plantas arbóreas que se encontram entre $10 \mathrm{~cm}$ de altura até o limite de diâmetro estabelecido no levantamento estrutural são definidos como regeneração natural.

Rollet (1969) considerou de regeneração os indivíduos com DAP inferior a $5 \mathrm{~cm}$ e Rollet (1978) considera ainda como regeneração as fases juvenis das espécies. Entretanto, cada classe diamétrica se constitui em regeneração da fração do povoamento da mesma espécie com diâmetro superior a essa classe.

Poggiani (1989) define o processo evolutivo da vegetação até a formação de uma floresta semelhante à primitiva, após o desmatamento parcial ou total de uma área, como regeneração natural, podendo esse processo durar de 50 a 100 anos nos trópicos.

\subsubsection{Estudos sobre a regeneração natural em matas ciliares}

Na sociedade capitalista em que vivemos, quando se pensa em um recurso, logo nos vem à mente o quanto ele poderá ser rentável, independente de ser recurso renovável ou não. Para que um recurso seja auto-sustentável e preservado, como uma floresta natural, por exemplo, é necessário que se conheça o potencial do recurso tanto atual como futuro. O potencial do presente é realizado através de inventários tanto qualitativo (análise florística ) quanto quantitativo (inventário e análise fitossociológica ). $\mathrm{O}$ potencial para o futuro é realizado através de prognósticos para os indivíduos adultos e de análise da regeneração natural, já que manejo natural, segundo Longo et al. (1993), baseia-se na extração racional das espécies madeireiras e não madeireiras, respeitando a estrutura original da mata, sendo a reposição do estoque feita naturalmente através da regeneração natural.

Alguns trabalhos de fitossociologia começam a dar ênfase à 
regeneração natural, como o trabalho realizado por Durigan \& Dias (1990), os quais estudaram a regeneração natural sob mata ciliar implantada a partir de 1973, na Fazenda Cananéia, Município de Cândido Mota, São Paulo. Visando a avaliar a possibilidade de a floresta plantada se perpetuar, eles verificaram que a floresta se apresentou com 191 espécies arbóreas, das quais 160 foram plantadas e as restantes surgiram espontaneamente em local onde não existia nenhum remanescente arbóreo. É provável que estas espécies tenham surgido devido à dispersão de propágulos, oriunda da vegetação do entorno.

Rodrigues (1991) realizou a análise florística, fitossociológica e a caracterização dos fatores ambientais de um remanescente de mata ciliar do Rio Passa Cinco, município de Ipeúna, São Paulo. Nesse trabalho, amostrou-se todos os indivíduos com $\mathrm{DAP}=5 \mathrm{~cm}$ e $\mathrm{DAP}<5 \mathrm{~cm}$ e maiores que $1 \mathrm{~m}$ de altura, além da caracterização florística das plântulas, para as quais se obteve 32 espécies.

O estudo da sucessão vegetal de espécies arbóreas da mata ciliar do córrego Capãozinho, no município de Sobradinho, Distrito Federal, foi realizado por Imaña-Encinas et al. (1995). Foram encontradas 70 espécies. Através de parâmetros fitossociológicos, índice relativo da sucessão natural e valor de importância, as espécies Piptocarpha macropoda, Copaifera langsdorffii, Rapanea leuconeura, Guatteria sellowiana e Amaioua guianensis foram consideradas como as mais importantes.

No entanto, a maioria dos trabalhos dá ênfase a uma ou poucas espécies, não havendo uma padronização quanto ao tipo de parcelas usadas no levantamento, qual o diâmetro considerado na amostragem dos indivíduos adultos e da regeneração, o que dificulta a comparação dos dados obtidos nos trabalhos. Outro tópico que deve ser discutido, está relacionado com à duração das observações e ao uso de parcelas permanentes, possibilitando, assim estudos futuros, tanto da estrutura, quanto da regeneração. 


\section{MATERIAL E MÉTODOS}

\subsection{Localização da área}

A Estação Experimental de Mogi Guaçú possui uma área de 4.031,12 ha, sendo que 3.050,41 ha correspondem à experimentação com Pinus e Eucalyptus e 980,71 ha correspondem à Estação Ecológica, que foi criada através do Decreto Estadual $\mathrm{n}^{\circ} 22.336 / 84$ de $07 / 06 / 84$, e que pertence ao Instituto Florestal. A área de estudo se trata de remanescente de mata ciliar, que acompanha o Rio Mogi Guaçú, com uma extensão de 19 km, Parente ${ }^{1}$.

A Fazenda Campininha, que abriga a Estação Ecológica, está localizada no Bairro Martinho Prado, no município de Mogi Guaçú. Este município se localiza na região fisiográfica denominada Depressão Periférica Paulista, entre os paralelos $22^{\circ} 15^{\prime}$ ' S e $22^{\circ} 30^{\prime} \mathrm{S}$ e entre os meridianos $47^{\circ} 00^{\prime} \mathrm{W}$. e $47^{\circ} 15^{\prime}$ W., com uma altitude média de $680 \mathrm{~m}$ (Batista, 1982) (Figura 1).

A vegetaçãoda Estação Ecológica de Mogi Guçú é caracterizada por florestas mesófilas semidecíduas ciliares, as quais se situam nas proximidades do leito do rio Mogi Guaçú e recebem influência direta do mesmo, quer por um lençol freático superficial, quer pelo regime hídrico que determina inundações temporárias. A situação mais comum é a ocorrência de um dique marginal, com áreas de declive por onde a água penetra para 0 interior da floresta, (no prelo). 
acompanhando depressões irregulares que, às vezes, formam lagoas de dimensões variadas proporcionando uma grande heterogeneidade ambiental (Leitão Filho et al., no prelo)(Figura 2 e 3 ).

Os solos estão classificados como latossolo vermelho-amarelo (LVA), latossolo vermelho-escuro (LE) e solos de planície de inundação (Batista, 1982), sendo que na área de estudo há o predomínio do solo de planície de inundação. 


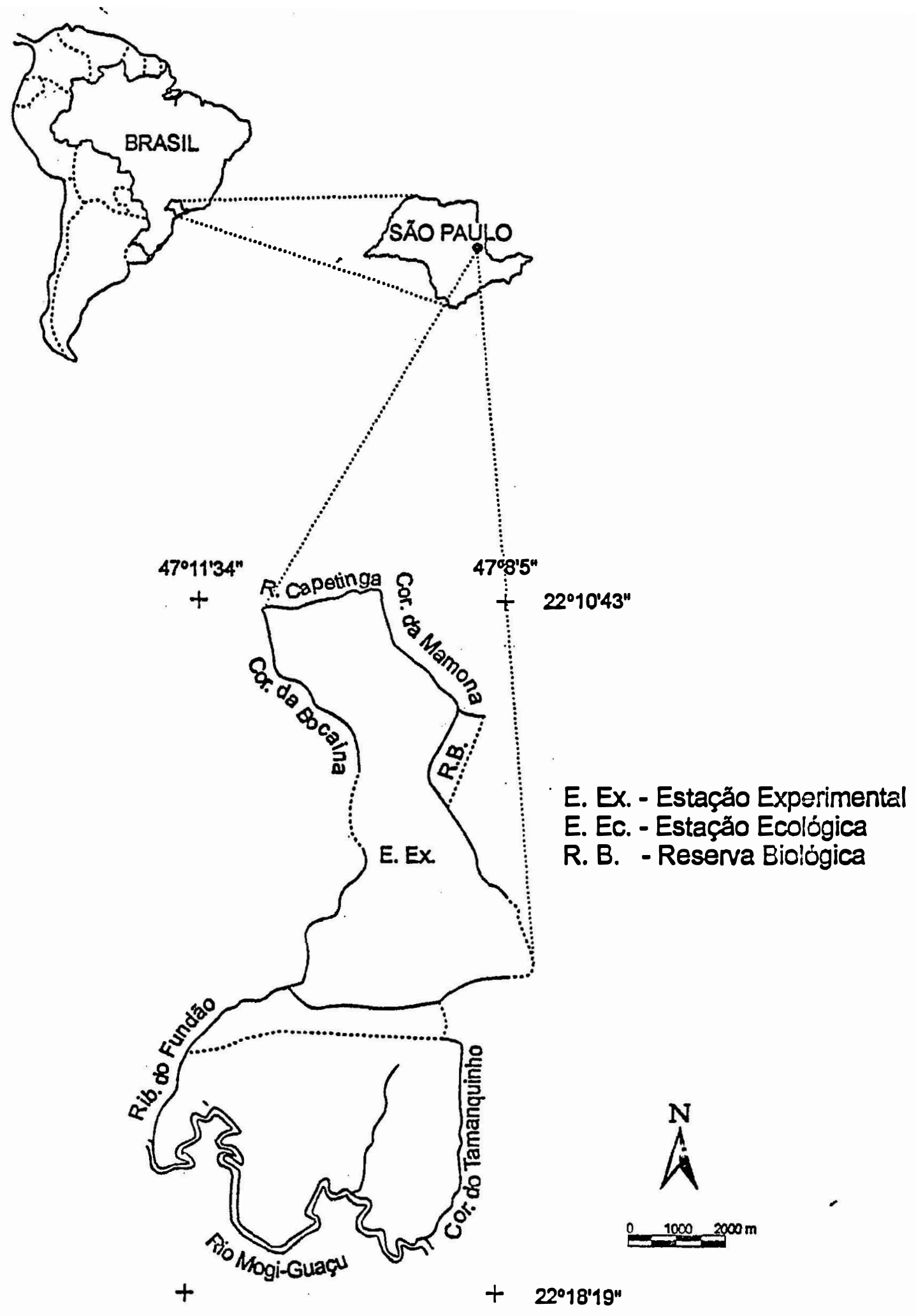

Figura 1 Localização da Estação Experimental de Mogi Guaçú, onde se encontra inserida à Estação Ecológica de Mogi Guaçú - SP. 


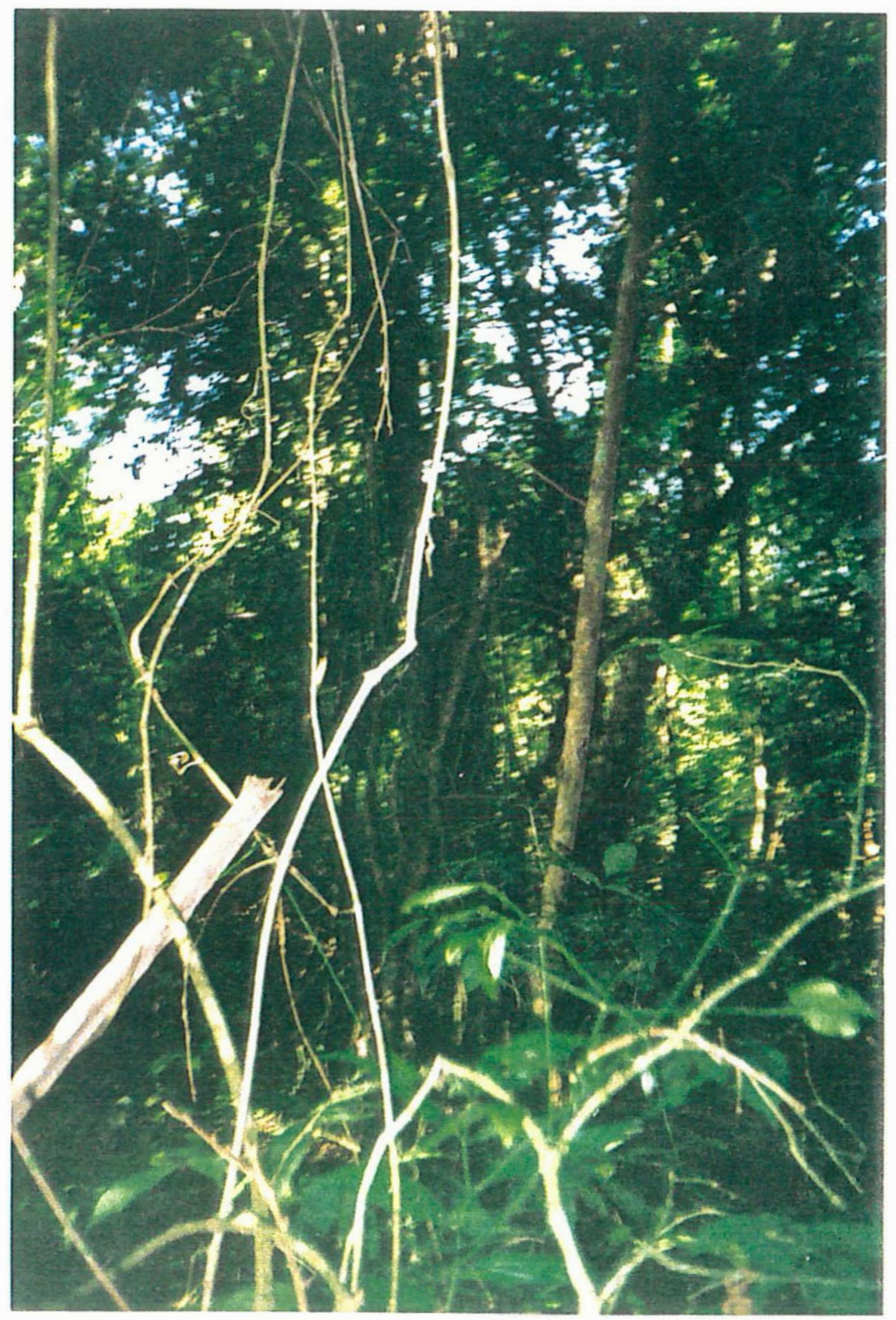

Figura 2. Vista do interior da mata ciliar do rio Mogi Guaçú, onde se observa a presença de lianas e capim navalha, Estação Ecológica de Mogi GuaçúSP. 


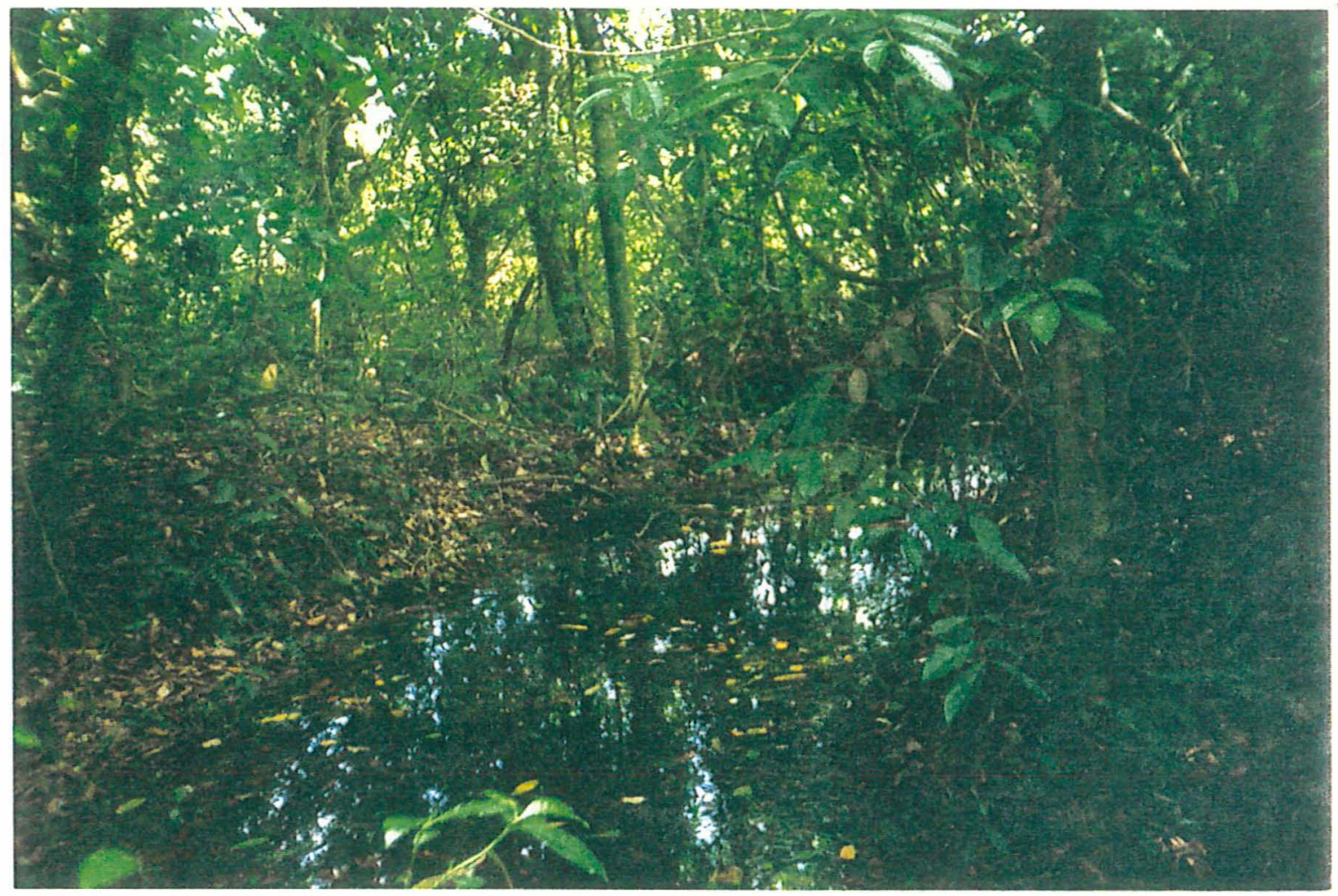

Figura 3. Vista do interior da mata ciliar do rio Mogi Guaçú, onde se observa a presença de água (acima) e uma área bem preservada (abaixo), Estação Ecológica de Mogi Guaçú - SP.

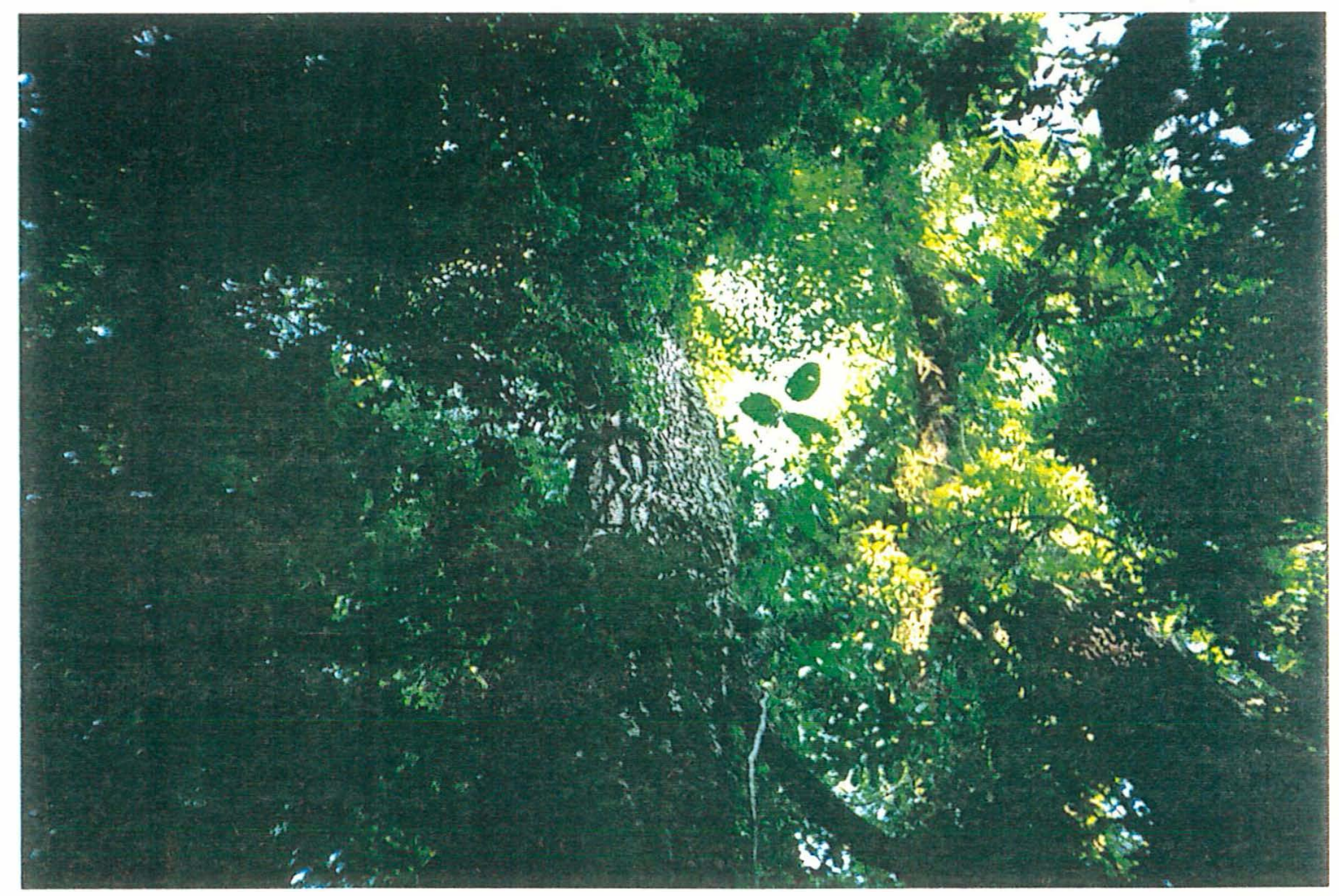




\subsection{Clima}

O clima predominante na região de Mogi Guaçú, segundo Köppen, é do tipo Cwa - temperado quente com estiagem no inverno (Batista, 1982). O total de chuvas no mês mais seco foi inferior a $30 \mathrm{~mm}$, apresentando temperatura média no mês mais quente acima de $22{ }^{\circ} \mathrm{C}$ e do mês mais frio abaixo de $18{ }^{\circ} \mathrm{C}$ (Brasil, 1960).

Os dados climáticos (temperatura e precipitação) para a área em estudo foram obtidos na Estação hidrometereológica de Santa Terezinha, pertencente à Champion Celulose e Papel, coletados ao longo de 10 anos, a partir de 1986. O balanço hídrico calculado pelo método de Thornthwaite \& Matter (1955) foi obtido através do programa de balanço hídrico para culturas anuais e perenes (Lier \& Dourado Neto, 1992).

A capacidade de armazenamento no solo usada foi de $100 \mathrm{~mm}$.

\subsection{Levantamento do estrato arbóreo}

\subsubsection{Florística e análise fitossociológica}

O método utilizado para o levantamento do estrato arbóreo foi o de parcelas retangulares, distribuídas aleatoriamente na área. Para o levantamento fitossociológico das espécies arbóreas foram locadas 10 parcelas permanentes de $10 \mathrm{~m}$ X $30 \mathrm{~m}\left(300 \mathrm{~m}^{2}\right)$. Os vértices foram marcados através de tubos de PVC (conduit) de $2 \frac{1}{2}$ " medindo $1,50 \mathrm{~cm}$ de comprimento e delimitados com barbante de algodão, preenchidos com cimento argamassa e arame de alumínio $n^{\circ} 8$. $O$ maior comprimento da parcela foi estabelecido perpendicularmente ao sentido do rio, e foi distribuído aleatoriamente em toda a sua extensão $(19 \mathrm{~km})$. Os 
indivíduos amostrados foram marcados com uma plaqueta de alumínio numerada, afixada com prego galvanizado.

Como critério de inclusão, foram medidos todos os indivíduos arbóreos com circunferência à altura do peito (CAP) iguais ou maiores que $15,70 \mathrm{~cm}$, inclusive árvores mortas em pé. Os indivíduos ramificados somente seriam incluídos se pelo menos uma das ramificações possuísse o CAP estipulado. De cada indivíduo, foram medidos o CAP e posteriormente convertida em diâmetro à altura do peito (DAP). A altura total foi estimada visualmente e também foi coletado material vegetativo e/ou reprodutivo para posterior herborização e identificação.

A identificação das plantas foi realizada através de comparação em herbários e consulta a especialistas da área de botânica. A classificação foi segundo o sistema de Cronquist (1981). Todo o material coletado e identificado foi incorporado ao Herbário do Departamento de Bôtanica da Escola Superior de Agricultura "Luiz de Queiroz".

A diversidade foi avaliada pelo índice de Shannon (Martins, 1991). Os parâmetros foram estimados para toda a área amostrada. As árvores mortas foram tratadas como um grupo, dentro da análise fitossociológica.

Os parâmetros estimados foram :

$$
\begin{aligned}
& \mathrm{DA}=\mathrm{n}_{\mathrm{i}} / \mathrm{ha} \\
& \mathrm{DR}=\frac{\left(\mathrm{n}_{\mathrm{i}} / \mathrm{ha}\right)}{(\mathrm{N} / \mathrm{ha})} \cdot 100 \\
& \mathrm{DoA}=\sum_{\mathrm{i}=1}^{\mathrm{n}} \mathrm{g} / \mathrm{ha} \\
& \mathrm{DoR}=\left(\frac{\mathrm{g} / \mathrm{ha}}{\mathrm{G} / \mathrm{ha}}\right) \cdot 100 \\
& \mathrm{FA}=\frac{\text { número de parcelas com ocorrência da espécie }}{\text { número total de parcelas }} \cdot 100
\end{aligned}
$$


$\mathrm{FR}=\left(\frac{\mathrm{FA}}{\sum \mathrm{FA}}\right) \cdot 100$

$\mathrm{IVI}=\mathrm{DR}+\mathrm{DoR}+\mathrm{FR}$

$\mathrm{IVC}=\mathrm{DR}+\mathrm{DoR}$

onde,

$\mathrm{DA}=$ densidade absoluta;

$\mathrm{DR}=$ densidade relativa;

$\mathrm{n}_{\mathrm{i}}=\mathrm{n}^{\mathrm{0}}$ total de indivíduos amostrados de cada espécie por unidade de área;

$\mathrm{N}=\mathrm{n}^{\mathrm{o}}$ total de indivíduos amostrados, de todas as espécies do levantamento;

ha $=$ área em hectare;

DoA = dominância absoluta $\mathrm{em} \mathrm{m}^{2} / \mathrm{ha}$;

$\mathrm{g}=\quad$ área seccional de cada espécie $\left(\mathrm{m}^{2}\right)$;

DoR $=$ dominância relativa $(\%)$

$\mathrm{G}=\quad$ área basal total das espécies por unidade de área;

$\mathrm{FA}=$ freqüência absoluta;

$\mathrm{FR}=$ freqüência relativa $(\%)$;

$\mathrm{VI}=\quad$ valor de importância.

A diversidade florística foi determinada através do índice de Shannon:

$\mathrm{H}^{\prime}=-\sum \mathrm{p}_{\mathrm{i}} \cdot \ln \mathrm{p}_{\mathrm{i}}$,

onde $\mathrm{P}_{\mathrm{i}}=\mathrm{n}_{\mathrm{i}} / \mathrm{N}$

$\mathrm{ni}=$ número de indivíduos da espécie

$\mathrm{N}=$ número total de indivíduos amostrados

Estes parâmetros, foram calculados utilizando-se o pacote System Analisys Statistics (SAS, 1986). 


\subsection{Levantamento da regeneração}

Para o levantamento dos indivíduos da regeneração foram utilizadas duas subparcelas de $1 \mathrm{~m} \times 1 \mathrm{~m}\left(1 \mathrm{~m}^{2}\right)$, distribuídas sistematicamente dentro de cada parcela de $10 \mathrm{~m} X 30 \mathrm{~m}$.A partir do centro do menor comprimento da parcela (10 m), loca-se uma subparcela a cada $10 \mathrm{~m}$, sendo duas subparcelas para cada parcela, perfazendo um total de 20 subparcelas. Os dados foram coletados em outubro de 1995, abril de 1996 e outubro de 1996 (a cada 6 meses), sendo realizadas, no total, três medições.

Em cada subparcela foram medidos e contados todos os indivíduos lenhosos maiores que de $0,10 \mathrm{~m}$ de altura e menores que $5 \mathrm{~cm}$ de DAP. Foram coletados indivíduos da mesma espécie que se encontravam próximos às subparcelas para posterior identificação, evitando, assim, causar grande dano à regeneração.

\subsection{Categorias sucessionais}

As espécies foram classificadas em quatro categorias sucessionais:

a ) pioneira (P);

b ) secundária inicial (SI);

c ) secundária tardia (ST);

d ) e uma categoria que englobou as que em função da carência de informações não puderam ser incluídas nas categorias citadas acima - foi denominada sem caracterização (SC).

A classificação foi realizada usando dados de bibliografia disponível (Gandolfi, 1991; Rodrigues et al., 1991; Gabriel, 1997; Leitão Filho , no prelo) e nas observações de campo. Optou-se pela inclusão e discussão das categorias, 
visando a fornecer dados que auxiliem a compreensão da dinâmica sucessional das matas ciliares. 


\section{RESULTADOS E DISCUSSÃO}

\subsection{Clima}

A Tabela 1 mostra as temperaturas médias mensais para um período de 10 anos (1986 - 1996) e, separadamente, para os anos de 1995 e 1996.

Observa-se que no período de 10 anos (Tabela 1) a temperatura média anual foi de $20,59^{\circ} \mathrm{C}$. Os meses mais frios foram junho e julho e os meses mais quentes, janeiro e fevereiro. A menor temperatura mensal ocorreu em junhos com $16,10^{\circ} \mathrm{Cs}$ e a maior, em fevereiro, $23,77^{\circ} \mathrm{C}$.

No ano de 1995 (Tabela 1), a temperatura média anual foi de $20,80^{\circ} \mathrm{C}$. Os meses mais frios foram junho e julho e os meses mais quentes janeiro e fevereiro. A temperatura mínima mensal desse ano foi em junho $\left(9,80^{\circ} \mathrm{C}\right)$ e a temperatura máxima mensal foi em janeiro $\left(25,09^{\circ} \mathrm{C}\right)$.

Para o ano de 1996 (Tabela 1), a temperatura média anual foi de $20,06^{\circ} \mathrm{C}$. Os meses mais frios foram junho e julho, e os mais quentes, fevereiro e março. A temperatura mínima mensal desse ano foi em julho, de $13,05^{\circ} \mathrm{C}$, e a máxima mensal foi em fevereiro $22,05^{\circ} \mathrm{C}$.

Foram calculados os balanços hídricos e construídos os gráficos dos mesmos (Figura 5) para o período de 10 anos (1986 - 1996) e para os anos de 1995 (Figura 6) e 1996 (Figura 7). 
Tabela 1 Temperaturas médias para o período de 10 anos (1986 - 1996), e para os anos de 1995 e 1996, da região da Estação Experimental de Mogi Guaçú-SP.

\begin{tabular}{cccc}
\hline Meses & Temperatura Média $\left({ }^{\circ} \mathrm{C}\right)$ & Temperatura Média $\left({ }^{0} \mathrm{C}\right)$ & Temperatura Média $\left({ }^{0} \mathrm{C}\right)$ \\
Jan & $1986-1996$ & 1995 & 1996 \\
Fev & 23,40 & 25,09 & 21,85 \\
Mar & 23,77 & 23,14 & 22,05 \\
Abr & 22,80 & 22,65 & 22,02 \\
Mai & 21,06 & 22,13 & 19,65 \\
Jun & 19,20 & 19,24 & 16,02 \\
Jul & 16,10 & 16,76 & 13,87 \\
Ago & 16,14 & 17,45 & 13,05 \\
Sete & 18,00 & 20,62 & 14,95 \\
Out & 19,50 & 20,30 & 16,04 \\
Nov & 21,44 & 20,13 & 19,04 \\
Dez & 22,92 & 21,00 & 19,16 \\
Ano & 22,80 & 21,06 & 20,06 \\
\hline
\end{tabular}

Para o período de 10 anos, como pode ser observado na Figura 5, houve uma deficiência hídrica para o local de estudo $(7 \mathrm{~mm})$. A precipitação média anual foi de $1296 \mathrm{~mm}$ e o excedente hídrico médio anual foi de $337 \mathrm{~mm}$. 


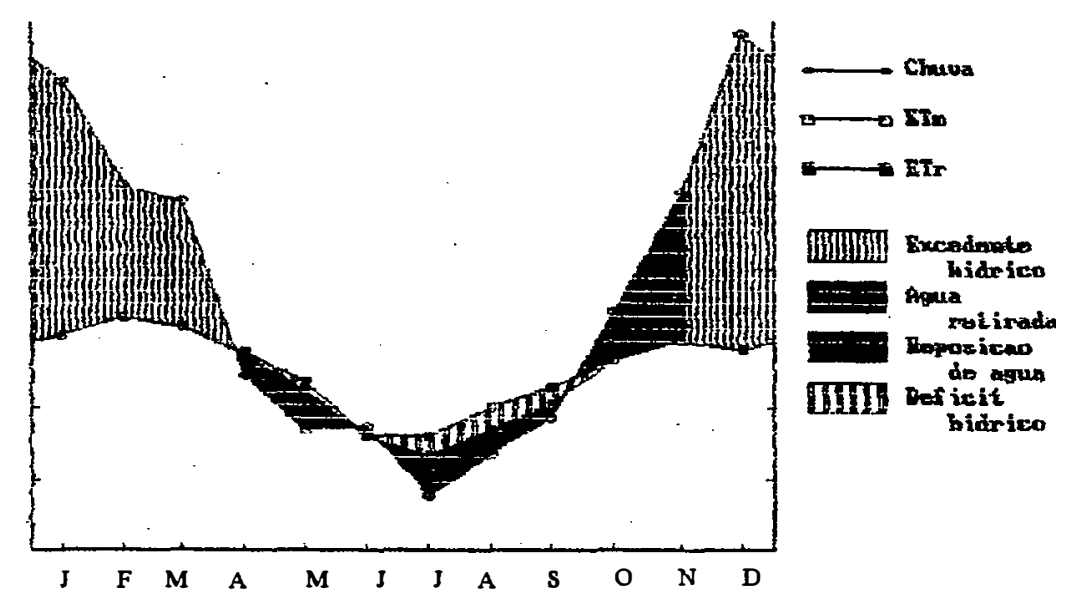

Figura 5 - Balanço hídrico (segundo Thorthwaite \& Mather, 1955), para a região da Estação Experimental de Mogi Guaçú-SP, baseado em dados de temperatura e precipitação de 1986 a 1996.

Na Figura 6, para o ano de 1995, observou-se que houve deficiência hídrica pronunciada de $159 \mathrm{~mm}$, sendo que o período seco se iniciou em maio, com $6 \mathrm{~mm}$ de deficiência, passando por junho e julho, culminando em agosto, com $59 \mathrm{~mm}$, e finalizando-se em setembro, com $34 \mathrm{~mm}$ de deficiência. Com relação a precipitações, o ano de 1995 apresentou uma média de $1315 \mathrm{~mm}$, valor superior em relação à média dos 10 anos, com altos índices de chuvas para os meses de janeiro $(252 \mathrm{~mm})$ e fevereiro $(481 \mathrm{~mm})$, ocasionando, dessa maneira, o excedente hídrico de $480 \mathrm{~mm}$, valor superior à referida média dos 10 anos. No entanto, o que foi verificado é que, mesmo registrando maior precipitação para este período e meses com excessivo índice de chuvas, o ano foi marcadamente seco, ocorrendo, para o mês de agosto, 0 mm de precipitação. 


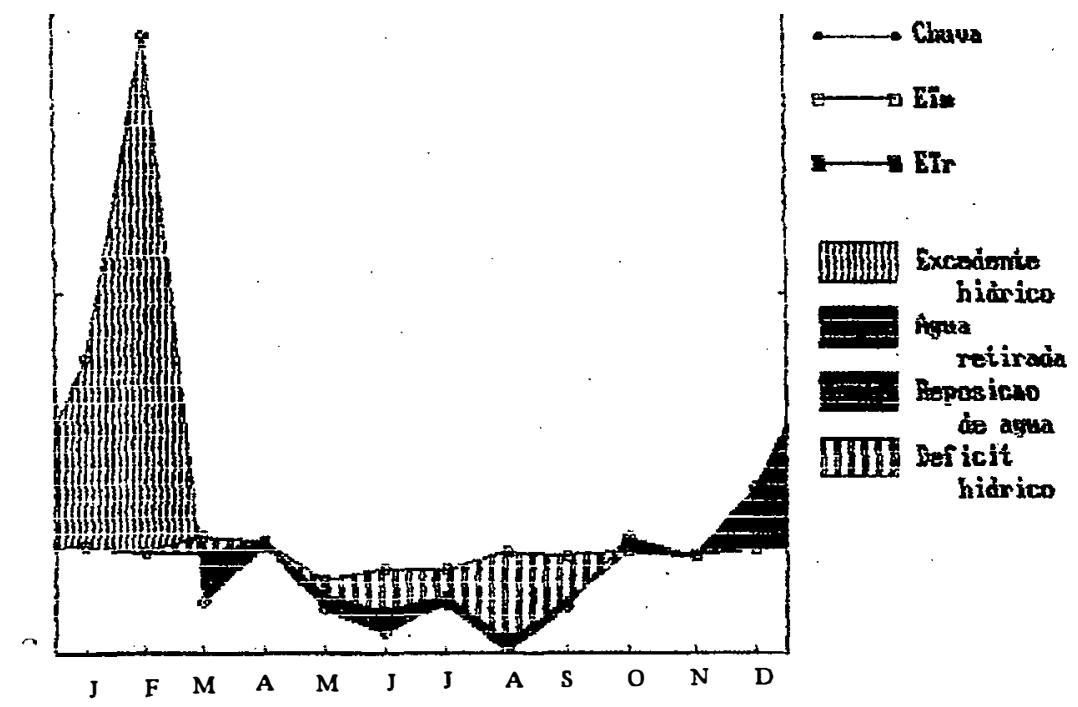

Figura 6 Balanço hídrico (segundo Thorthwaite \& Mather, 1955), para a região da Estação Experimental de Mogi Guaçú- SP, baseado em dados de temperatura e precipitação de 1995.

Na Figura 7, observa-se que houve deficiência hídrica de $46 \mathrm{~mm}$ no ano de 1996, valor menor quando comparado ao ano anterior, sendo que o período seco se iniciou em abril, com $4 \mathrm{~mm}$ de deficiência, passando por maio e junho, culminando em julho com $18 \mathrm{~mm}$ e finalizando em agosto com $14 \mathrm{~mm}$ de deficiência. Para os valores de precipitação, o ano de 1996 apresentou uma precipitação média de $1574 \mathrm{~mm}$, valor bastante superior em relação à média dos 10 anos, com índices de chuvas bem distribuídas e com maiores índices para os meses de março $(275 \mathrm{~mm})$ e dezembro $(247 \mathrm{~mm})$, ocasionando o excedente hídrico de $830 \mathrm{~mm}$, valor bastante superior em relação à média dos 10 anos. 


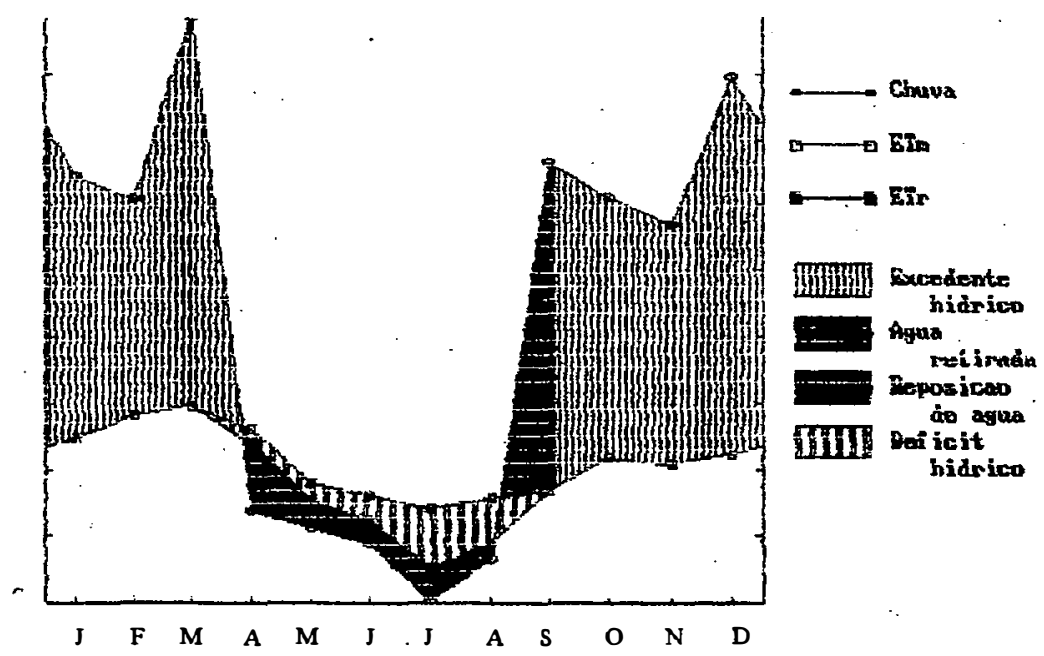

Figura 7 Balanço hídrico (segundo Thorthwaite \& Mather, 1955), para a região da Estação Experimental de Mogi Guaçú-SP, baseado em dados de temperatura e precipitação de 1996.

\subsection{Análise fitossociológica e florística}

No levantamento florístico do estrato arbustivo-arbóreo foram amostrados 349 indivíduos, 43 espécies e 20 famílias.

A Tabela 2 apresenta, por ordem alfabética, as famílias as espécies, os nomes vulgares da região quando disponíveis e os grupos ecológicos.

As famílias com maior riqueza de espécies foram Euphorbiaceae (6), Myrtaceae (6), Fabaceae (3), Lauraceae (3), Mimosaceae (3) e Sapindaceae (3), as quais somaram 55,81\% da flora amostrada. Quatorze familias das vinte presentes ocorreram com baixa densidade, tendo um ou dois indivíduos por espécies, o que corresponde a $70,00 \%$ da flora amostrada. Estes resultados podem ter sido conseqüência da amostragem ou podem ser devidos à característica observada geralmente em florestas tropicais, onde predomina a riqueza de espécies com 
Tabela 2 - Lista das espécies amostradas dos indivíduos arbóreos na mata ciliar do rio Mogi Guaçú, Município de Mogi Guaçú,SP, em ordem alfabética de famílias, acompanhadas de seus nomes vulgares quando conhecidos e grupos ecológicos.

\begin{tabular}{|c|c|c|c|}
\hline FAMIILIA & NOME CIENTIFICO & NOME VULGAR & $\mathrm{GE}(*)$ \\
\hline Anacardiaceae & Tapirira guianensis Aubl. & Peito-de-pomba & SI \\
\hline Annonaceae & Duguetia lanceolata St.Hil. & Pindaíba & ST \\
\hline \multirow[t]{2}{*}{ Arecaceae } & Euterpe edulis Mart. & Palmito & SI \\
\hline & Syagrus romanzoffiana (Cham.) Glassman & Gerivá & SI \\
\hline Caesalpiniaceae & Copaifera langsdorffii Desf. & Oleo Copaiba & ST \\
\hline Combrelaceae & Terminalia triflora Griseb. & Amarelinho & SI \\
\hline \multirow[t]{5}{*}{ Euphorbiaceae } & Alchornea glandulosa Poepp. \& Endl. & Tapiá & $\mathbf{P}$ \\
\hline & Croton floribundus Spreng. & Capixingui & $\mathbf{P}$ \\
\hline & Pera glabrata (Schott.) Baill. & Pera & SI \\
\hline & Savia dictyocarpa Kuhlm. & Guaraiúva & ST \\
\hline & Sebastiana klotzchiana (Muell. Arg.) Muell. Arg. & Sebastiana & $\mathbf{P}$ \\
\hline \multirow[t]{3}{*}{ Fabaceae } & Andira fraxinifolia Benth. & Mata-baratas & SI \\
\hline & Cyclolobium vecchi A. Samp. ex Hoehne & Louveira & ST \\
\hline & Machaerium brasiliensis Vog. & & SI \\
\hline Flacourtiaceae & Casearia sylvestris Sw. & Guaçatonga & $\mathbf{P}$ \\
\hline \multirow[t]{3}{*}{ Lauraceae } & Nectandra megapotamica (Spreng.) Mez & Canelinha & SI \\
\hline & Nectandra oppositifolia & Canela & ST \\
\hline & Ocotea $s p$ & & \\
\hline Lecythidaceae & Cariniana legalis (Mart.) Kuntze. & Jequitibá-branco & ST \\
\hline Melastomataceae & Miconia langsdorfii Cogn. & & $P$ \\
\hline \multirow[t]{2}{*}{ Meliaceae } & Guarea guidonea (L.) Sleumer. & Marinheiro & SI \\
\hline & Trichilia catigua Adr. Juss. & Catiguá & ST \\
\hline \multirow[t]{2}{*}{ Mimosaceae } & Anadenanthera colubrina (Vell.) Brenan & Angico branco & $\mathbf{P}$ \\
\hline & Enterolobium contortisiliquum (Vell.) Morong & Orelha de negro & SI \\
\hline
\end{tabular}


Inga vera sub affines

Moraceae $\quad$ Sorocea bonplandii (Baill.) Burg.

Myrtaceae

Calyptranthes concinna D.C.

ST

Eugenia glazioviana Kiaersk.

St

Eugenia florida D.C.

Sc

Eugenia hyemalis Cambess.

ST

Eugenia sp

SC

Myrcia sp.

SC

Phytolacaceae

Gallesia integrifolia (Spreng.) Harms

Pau d'alho

ST

Rubiaceae

Genipa americana $\mathrm{L}$.

Genipapo

SC

Sapindaceae

Cupania vernalis Camb.

Pau de espeto

SI

Matayba juglandifolia (Camb.) Radlk

SI

Matayba elaegnoides Radlk

SI

Tiliaceae

Luehea divaricata Mart.

Açoita cavalo

SI

Indeterminadas

Desconhecida

SC

Desconhecida 1

$\mathrm{SC}$

Desconhecida 2

SC

baixa densidade.

Nos trabalhos realizados às margens do rio Mogi Guaçú, a família Euphorbiaceae, Fabaceae, Myrtaceae e Mimosaceae aparecem nos primeiros lugares nos trabalhos realizados por Gibbs \& Leitão (1978), Mantovani (1989), Gibbs et al (1980) e Leitão Filho et al. (no prelo).

Se fosse considerado o sistema de classificação de Engler (1954) a família Leguminosae apresentaria a maior riqueza florística com 7 espécies amostradas.

Comparando-se as famílias que apresentaram maior riqueza florística com os resultados obtidos por diversos autores em mata ciliar no Estado de São 
Paulo, observou-se que, de maneira geral, houve grande semelhança entre as matas estudadas (Gibbs \& Leitão Filho, 1978; Gibbs, 1980; Marchiori, 1989; Mencacci et al., 1992; Rodrigues, 1991; Leitão Filho et al., no prelo entre outros).

Os resultados obtidos no presente estudo confirmam a colocação de Leitão Filho (1982) de que as famílias de maior riqueza nas formações florestais ciliares são Leguminosae, Myrtaceae, Lauraceae, Euphorbiaceae e Rubiaceae.

\subsubsection{Levantamento geral para as espécies}

Foram amostrados, no levantamento fitossociológico, 349 indivíduos ( $91,40 \%$ vivos e $8,60 \%$ mortos) pertencentes a 42 espécies. Considerou-se, ainda o grupo das árvores mortas em pé.

Os indivíduos amostrados no levantamento apresentaram área basal de $25,22 \mathrm{~m}^{2}$. A densidade estimada foi de $1163 \mathrm{ind} . / \mathrm{ha}$.

$\mathrm{O}$ diâmetro médio encontrado no presente estudo foi de $14,65 \mathrm{~cm}$. O diâmetro máximo foi de $72,10 \mathrm{~cm}$, medido em um indivíduo de Enterolobium contortisiliquum. O diâmetro mínimo de $5,00 \mathrm{~cm}$ foi medido em indivíduos de Eugenia sp e Sebastiana klotzchiana.

A altura média amostrada no levantamento foi de $8,26 \mathrm{~m}$. A altura máxima foi de $22,0 \mathrm{~m}$, medida em um indivíduo de Gallesia integrifolia, e a altura mínima foi de 2,0 m, medida em um indivíduo de Eugenia sp.

Os parâmetros fitossociológicos para as espécies do estrato arbustivoarbóreo estão apresentados em anexo (Apêndice 1 ), em ordem decrescente de VI (Valor de Importância), para a mata ciliar estudada.

Através da Figura 8, verifica-se que as 10 espécies de maior densidade absoluta foram Miconia langsdorfii, com 167 indivíduos (14,33 \%); Sebastiana klotzchiana, com 140 indivíduos (12,03\%); Eugenia sp, com 120 indivíduos 
(10,32\%); Guarea guidonea, com 67 indivíduos (5,73\%); Gallesia integrifolia, 63 indivíduos (5,44\%); Cyclolobium vecchi, com 53 indivíduos (4,58\%); Inga vera, com 47 indivíduos (4,01\%); Alchornea glandulosa, com 43 indivíduos (3,72 \%); Casearia sylvestris, com 43 indivíduos (3,72\%); e Duguetia lanceolata, com 30 indivíduos $(2,58 \%)$.

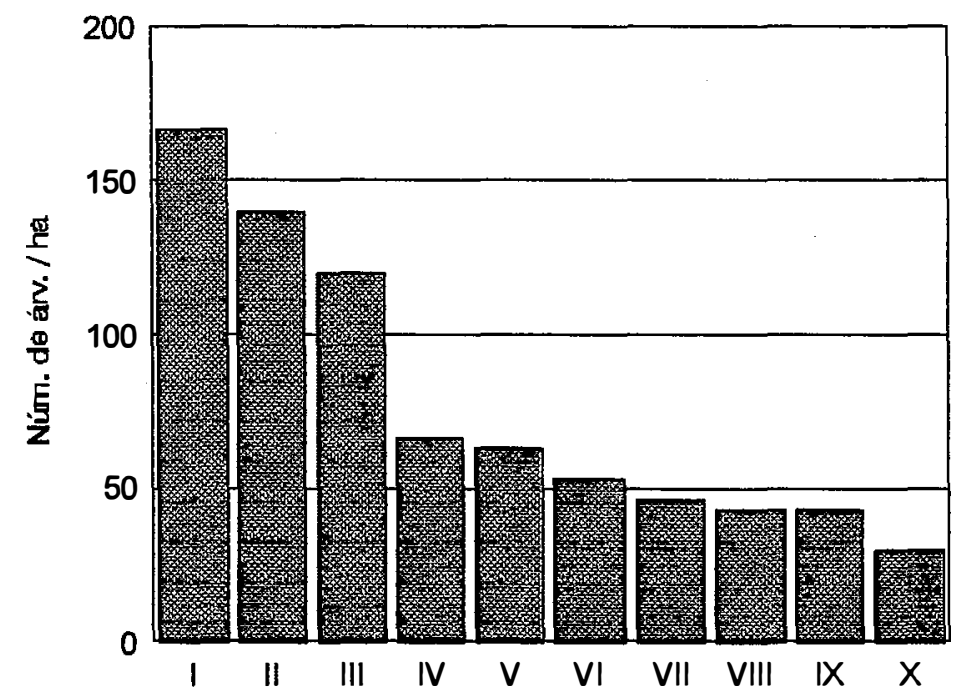

I - Miconia langsdorfii; II - Sebastiana klotzchiana; III - Eugenia SP; IV - Guarea guidonea; V - Gallesia integrifolia; VI - Cyclolobium vecchi; VII - Inga vera; VIII - Alchornea glandulosa; LX - Casearia sylvestris; X - Duguetia lanceolata.

Figura 8 - Ordenação por densidade absoluta (DA), das principais espécies arbóreas amostradas no levantamento fitossociológico da mata ciliar do rio Mogi Guaçú, Mogi Guaçú - SP.

Analisando os dados da Figura 9, observa-se que a espécie de maior valor para a dominância absoluta foi Gallesia integrifolia, com $2,79 \mathrm{~m}^{2} / \mathrm{ha}(11,05$ $\%)$; seguida por Sebastiana klotzchiana, com 2,58 m²/ha (10,46 \%); Miconia langsdorfii, com 2,08 $\mathrm{m}^{2} / \mathrm{ha}(8,26 \%) ;$ Alchornea glandulosa, com $2,08 \mathrm{~m}^{2} / \mathrm{ha}$ (8,25\%); Inga vera, com $1,83 \mathrm{~m}^{2} / \mathrm{ha}$ (7,28 \%); Cyclolobium vecchi, com 1,49 
$\mathrm{m}^{2} / \mathrm{ha}(5,91 \%)$; Enterolobium contortisiliquum, com $1,36 \mathrm{~m}^{2} / \mathrm{ha}(5,40 \%)$; Nectandra megapotamica, com 1,03 $\mathrm{m}^{2}$ (4,10\%); Nectandra oppositifolia, 0,89 $\mathrm{m}^{2} / \mathrm{ha}(3,52 \%)$; e Duguetia lanceolata, com $0,78 \mathrm{~m}^{2} / \mathrm{ha}(3,07 \%)$.

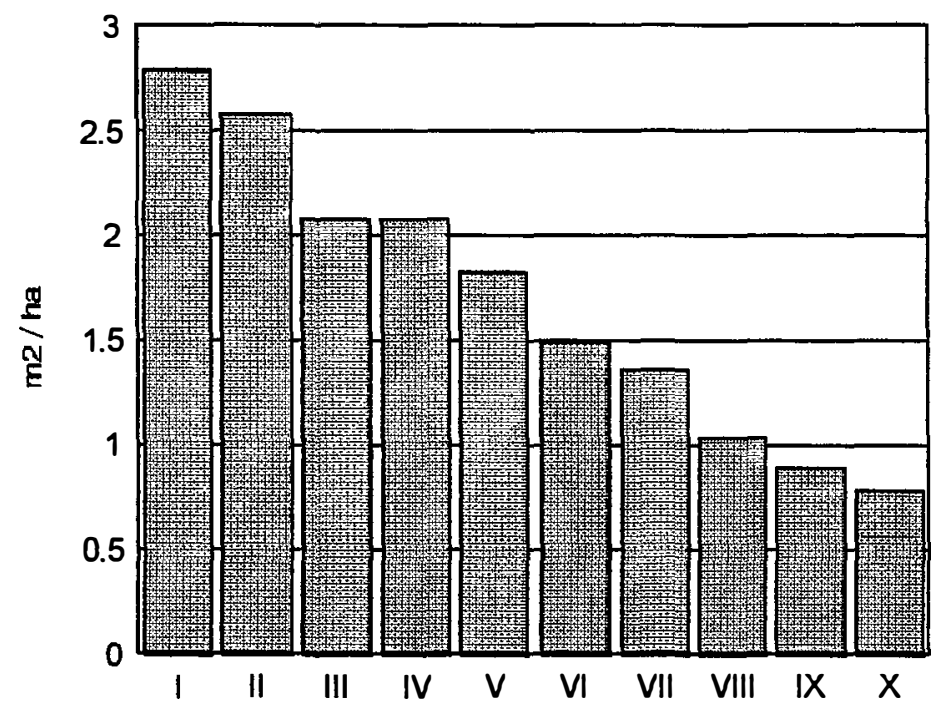

I - Gallesia integrifolia; II - Sebastiana klotzchiana; III - Miconia langsdorfii; IV - Alchornea glandulosa; V - Inga vera; VI - Cyclolobium vecchi; VII - Enterolobium fusitolito; VIII - Nectandra megapotamica; IX - Nectandra oppositifolia; X - Duguetia lanceolata.

Figura 9 - Ordenação por dominância absoluta (DoA), das principais espécies arbóreas amostradas no levantamento fitossociológico da mata ciliar do rio Mogi Guaçú, Mogi Guaçú - SP.

Com relação à freqüência absoluta, a Figura 10 mostra que as espécies Alchornea glandulosa e Sebastiana klotzchiana foram as mais freqüentes da vegetação, sendo amostradas em 70 \% das parcelas, seguidas por Eugenia sp e Miconia langsdorfii, que foram amostradas em $60 \%$ das parcelas; Guarea guidonea e Casearia sylvestris, que foram amostradas em $50 \%$ das parcelas; Gallesia integrifolia e Eugenia flórida, que foram amostradas em $40 \%$ das 
parcelas, Cyclolobium vecchi e Inga vera, que foram amostradas em $30 \%$ das parcelas.

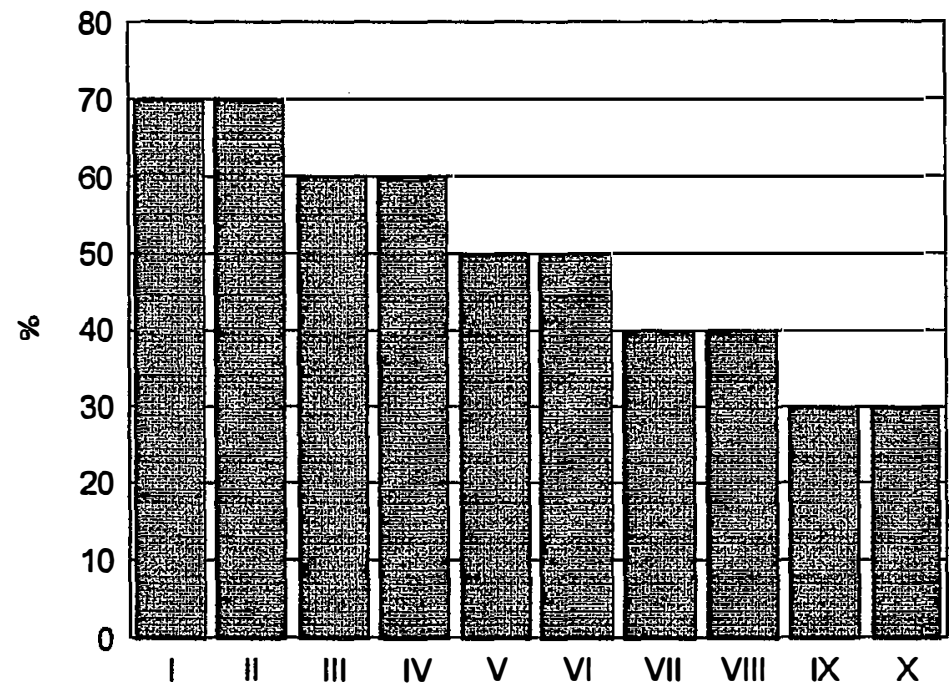

I - Sebastiana klotzchiana; II - Alchornea glandulosa; II - Miconia langsdorfi; IV - Eugenia sp;

V - Guarea guidonea; VI - Casearia sylvestris; VII - Gallesia integrifolia; VIII - Eugenia florida; $\mathrm{IX}$ - Cyclolobium vecchi; $\mathrm{X}$ - Inga vera.

Figura 10 - Ordenação por freqüência absoluta (FA), das principais espécies arbóreas amostradas no levantamento fitossociológico da mata ciliar do rio Mogi Guaçú, Mogi Guaçú - SP.

Pode-se observar na Figura 11 que as 10 espécies mais importantes com relação ao VI são Sebastiana klotzchiana, com 28,65 \%; Miconia langsdorfii, com 28,05\%; Gallesia integrifolia, com 20,13\%; Alchornea glandulosa, com 18,33; Eugenia sp, com 17,84 \%; Inga vera, com 14,04\%; Cyclolobium vecchi, com 13,22 \%; Guarea guidonea, com 12,93 \%; Casearia sylvestris, com 10,83\%; e Nectandra megapotamica, com 8,55\%, que, juntas, somaram $54,55 \%$ do VI total. Enquanto isso as 35 espécies restantes somaram $45,45 \%$ do VI total.

Na Figura 12, que ordena as espécies por VC (Valor de Cobertura), 


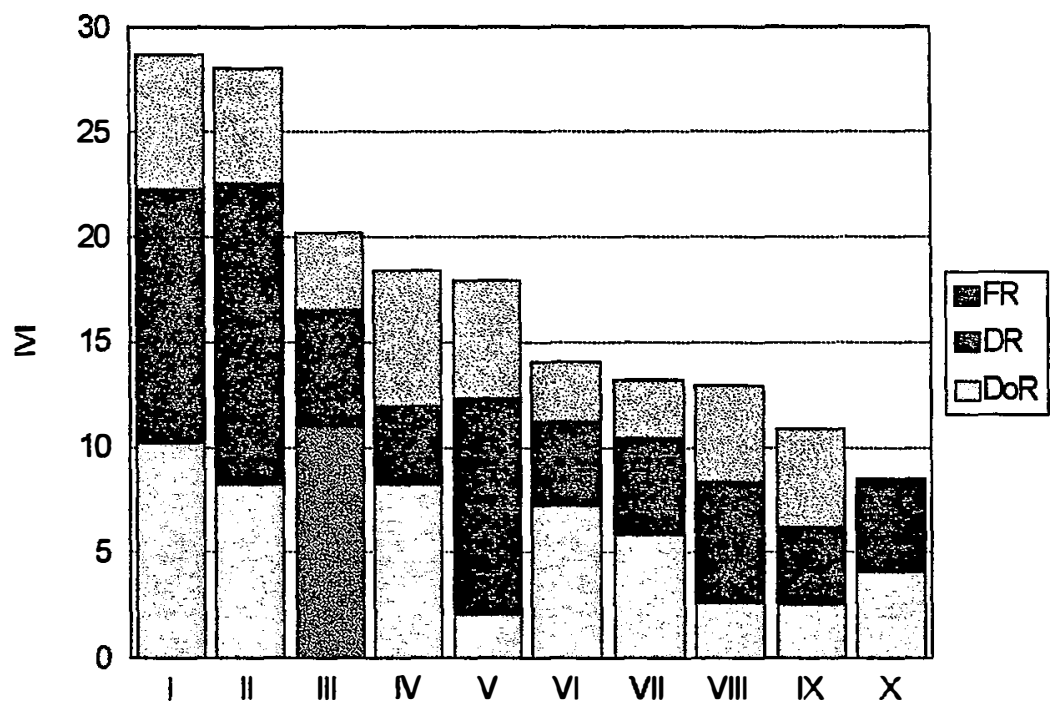

I - Sebastiana klotzchiana; II - Miconia langsdorfi; III - Gallesia integrifolia; IV - Alchornea glandulosa; V - Eugenia sp; VI - Inga vera; VII - Cyclolobium vecchi; VIII - Guarea guidonea IX - Casearia sylvestris; X - Nectandra megapotamica.

Figura 11 - Ordenação por valor de importância (VI), das principais espécies arbóreas amostradas no levantamento fitossociológico da mata ciliar do rio Mogi Guaçú, Mogi Guaçú - SP.

podem ser observadas as espécies Miconia langsdorfii, com 22,59\%; Sebastiana klotzchiana, com 22,28 \%; Gallesia integrifolia, com 16,50\%; Eugenia sp, com 12,38 \%; Alchornea glandulosa, com 11,97 \%; Inga vera, com 11,29\%; Cyclolobium vecchi, com 10,49\%; Guarea guidonea, com 8,38 \%; Casearia sylvestris, com 6,28\%; e Nectandra megapotamica, com 5,82\%, que, juntas, somaram $72,11 \%$ do VC total. Enquanto isso as 35 espécies restantes somaram $27,90 \%$ do VC total. 


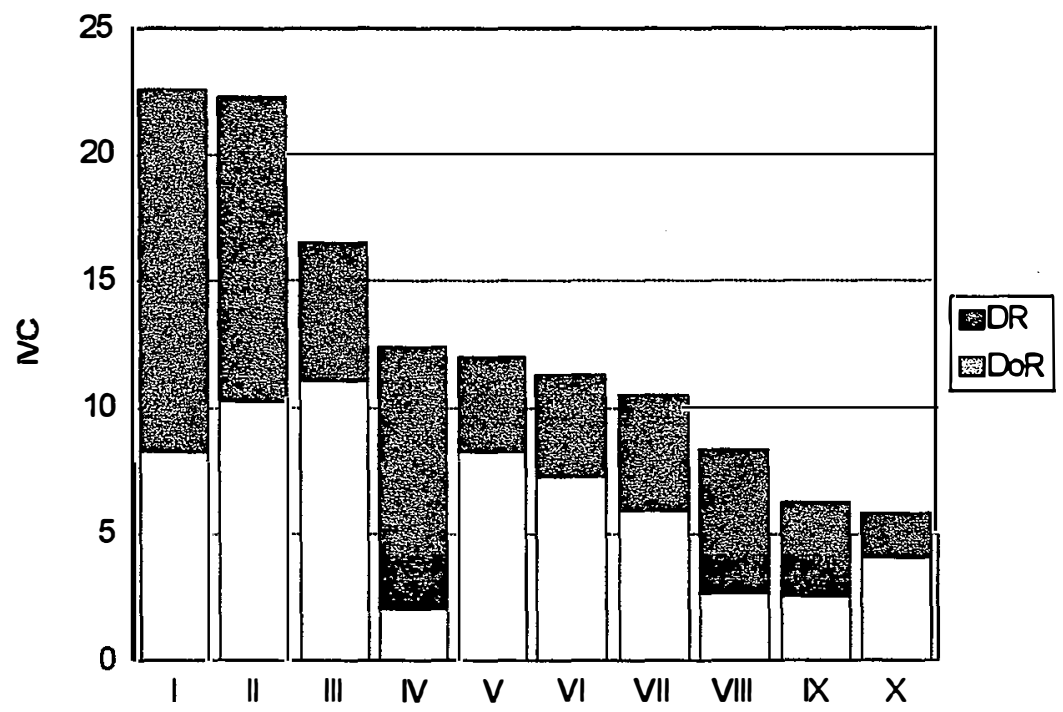

I - Miconia langsdorfii; II Sebastiana klotzchiana; III - Gallesia integrifolia; IV - Eugenia sp; V - Alchornea glandulosa; VI - Inga vera; VII - Cyclolobium vecchi; VIII - Guarea guidonea IX - Casearia sylvestris; X - Nectandra megapotamica.

Figura 12 - Ordenação por valor de cobertura (VC), das principais espécies arbóreas amostradas no levantamento fitossociológico da mata ciliar do rio Mogi Guaçú, Mogi Guaçú - SP.

O decréscimo do VI das 10 espécies mais importantes foi gradual, indicando que a estrutura da mata não está dominada por apenas uma ou duas espécies. Estas espécies também ocuparam as 10 primeiras posições no $\mathrm{VC}$, com inversão das posições de Sebastiana klotzchiana por Miconia langsdorfii e Alchornea glandulosa por Eugenia sp.

Das espécies amostradas na Figura 11 Gallesia integrifolia, Sebastiana klotzchiana, Miconia langsdorfii e Alchornea glandulosa tiveram em seus VIs contribuição expressiva devido à dominância absoluta (DoA), indicando que estas espécies foram consideradas importantes pela grande biomassa que apresentaram.

As espécies Miconia langsdorfii, Sebastiana klotzchiana e Eugenia sp tiveram contribuição expressiva devido à densidade absoluta (DA). Estas espécies 
foram consideradas importantes pelo grande número de indivíduos que apresentaram e não pela biomassa das mesmas.

Das 10 espécies de maior VI, Sebastiana klotzchiana, Alchornea glandulosa, Miconia langsdorfii e Eugenia sp ocorreram acima de $50 \%$ das parcelas, indicando,assim, uma distribuição aleatória na mata estudada.

Os resultados deste trabalho corroboram com os estudos realizados por outros autores em matas ciliares como Bertoni (1984), Mantovani (1989), Gibbs \& Leitão Filho (1978, 1980), Rodrigues (1991), entre outros, mostraram que a composição florística das matas ciliares é muito heterogênea. Isso se deve principalmente à interação de espécies típicas de matas de áreas inundáveis com espécies características de floresta de planalto, das vegetações circundantes e da heterogeneidade ambiental.

Alguns gêneros apresentam adaptações anatômicas no lenho para suportar condições de saturação hídrica, como Croton, Guarea, Sebastiana e Inga (Mazzoni-Viveiros \& Luchi, 1989). Todos os gêneros citados foram amostrados no presente estudo.

Oliveira Filho (1989, 1994), Rodrigues (1991), Joly (1986), Gianotti (1988), entre outros pesquisadores, verificaram uma nítida diferenciação da composição florística e estrutura das matas ciliares, devido, principalmente, à topografia das margens, ao tipo de solo, e à influência das cheias. Esta variabilidade ambiental encontrada dentro das matas ciliares dificulta a delimitação do ambiente físico da mata, particularmente da mata ciliar do rio Mogi Guaçú, onde a presença de lagoas proporciona ambientes bastante distintos, contribuindo para a diversidade das espécies. 


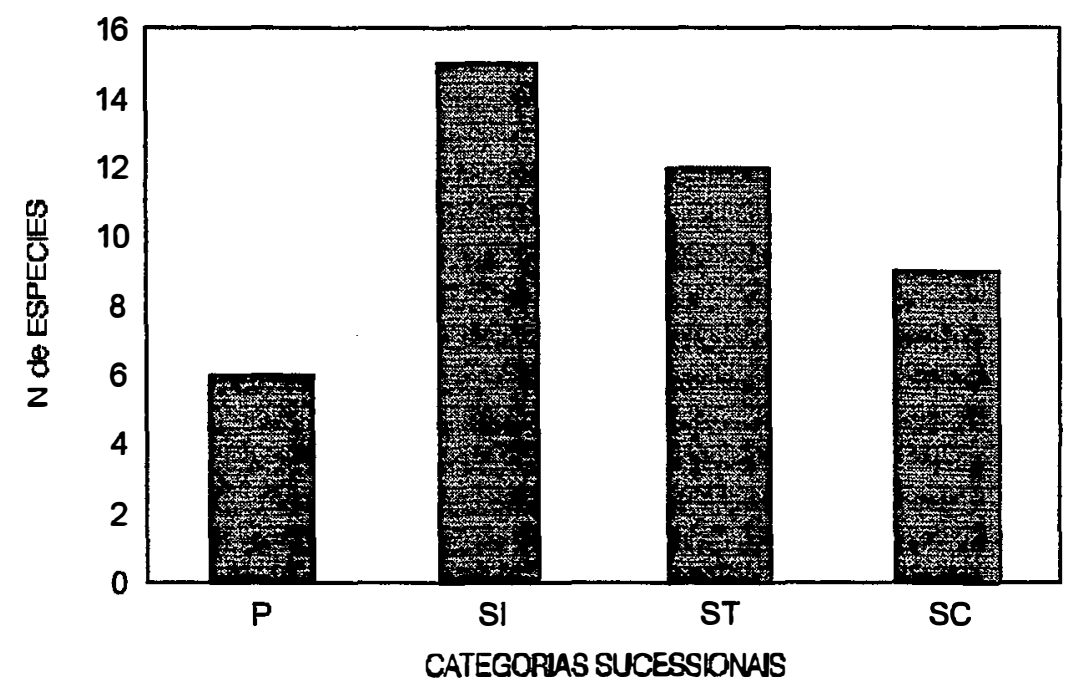

Figura 13 - Classificação sucessional do número de espécies, por grupo ecológico no levantamento fitossociológico da mata ciliar do rio Mogi Guaçú, Mogi Guaçú - SP.

A Figura 13 mostra que 40,48\% das espécies amostradas são secundárias iniciais, seguidas pelo grupo das espécies secundárias tardias com $21,43 \%$. As pioneiras contribuíram com $14,29 \%$ e as espécies que não possuem classificação definida representam $23,91 \%$, um percentual bastante elevado que poderia modificar significativamente os resultados acima.

A mata objeto deste estudo apresenta em todos os parâmetros calculados as três primeiras espécies, caracterizadas como pioneiras e secundária inicial, isso nos leva a afirmar que a mata está no estádio de início de sucessão, o que concorda com as observações de campo.

Este estádio inicial de sucessão pode ser explicado possivelmente pelo fato de a própria existência dos cursos d'água que permitir a entrada dos raios solares pelas bordas, possibilitando, então, o estabelecimento de espécies de início de sucessão. Pode ser atribuído também ao histórico de perturbação da área: em 
um passado recente há cerca de 30 anos, ocorreu o corte seletivo de árvores nobres na área. Os indivíduos estabelecidos em locais sujeitos a inundações periódicas e geadas ocasionais, provavelmente, apresentam um tempo de vida menor. $\mathrm{Na}$ área também ocorrem ventos fortes, o que contribui para a queda destes indivíduos, formando, desta maneira, pequenas clareiras onde o estabelecimento de espécies pioneiras é predominante. Observa-se, dessa maneira, uma mata com dossel baixo e aberto, com presença de espécies características de degradação com alta incidência de cipós e capim navalha. Verifica-se, também, um subosque rico no gênero Psycotria, principalmente nas áreas cujo dossel é mais aberto, o que não se observa na mata do Português e, principalmente, na mata da Figueira, que são as mais preservadas, com subosque mais fechado.

\subsubsection{2. Índice de diversidade e equabilidade}

A equabilidade $\left(\mathrm{J}^{\prime}\right)$ estimada foi de 0,82 e o índice de diversidade de Shannon $\left(\mathrm{H}^{\prime}\right)$ foi estimado em 3,07. $\mathrm{O}$ índice foi semelhante àqueles encontrados na maioria dos levantamentos no Estado de São Paulo, como está ilustrado na Tabela 3.

A equabilidade encontrada por Leitão filho (no prelo), foi de 0,81 para uma área próxima à área estudada.

O menor valor observado de diversidade foi obtido no estudo realizado por Marchiori (1989) em mata ciliar no município de Jaboticabal, e o maior valor foi encontrado por Nicolini Gabriel \& Pagano (1993) em um estudo realizado na mata ciliar mesófila semidecídua no município de Jaú. A grande variação dos valores de diversidade é influenciada por método amostral, tamanho da área amostrada, classe de diâmetro mínimo definida para a inclusão dos indivíduos, 
Tabela 3- Índices de diversidade de Shannon (H'), obtidos de trabalhos fitossociológico efetuados em matas ciliares no Estado de São Paulo.

\begin{tabular}{|c|c|c|c|}
\hline Local & A s três espécies com maiores VI & $\overline{\mathrm{H}^{\prime}}$ & Autores \\
\hline Mogi Guaçú & S. klotzchiana, C. vecchi, G. americana & 3,16 & Gibbs \& Leitão Filho, 1978 \\
\hline Mogi Guaçú & L. muelbergianus, $M$. paraguariense, I. uruguensis & 3,23 & Leitão Filho et al., 1996 \\
\hline Mogi Guaçú & S. klotzchiana, M. langsdorfii, G. integrifolia & 3,07 & Passos, 1998 \\
\hline Rio Claro & Inga aff uruguensis, $S$. brasiliensis, 1 . uruguensis & 2,88 & Mencacci, 1991 \\
\hline Itirapina & $V$. tucanorum, M.lingua, $R$. umbellata & 3,74 & Giannotti, 1988 \\
\hline Itirapina & Urera basifora, Chorisia especiosa, Piper & 3,61 & Kotchetkoff-Henriques \& Joly, 1994 \\
\hline Brotas & Actinostenon comunis, C. tomentosum, $M$. nigra & 3,06 & Salis, 1990 \\
\hline Ipeúna & & 3,60 & Mantovani et al., 1986 \\
\hline Ipeúna & A. communis, C. miner, M.eleagnoides & 3,50 & Rodrigues, 1991 \\
\hline Porto Ferreira & Metrodora nigra, Galipa multiflora, C. estrllensis & 3,68 & Bertoni, 1984 \\
\hline Jaú & Ficus citrifolia, Gallesia integrifolia & 4,06 & Nicolini-Gabriel \& Pagano, 1993 \\
\hline Jaboticabal & M. nigra, Astronium graveolens, $A$. polyneuron & 3,05 & Pinto et al., 1990 \\
\hline Jaboticabal & A. graveolens, C. padystadya, , C. estrllensis & 2,82 & Marchiori, 1989 \\
\hline Ubatuba & & 3,99 & Sanchez, 1994 \\
\hline Ibiporã & S. bonplandi, G. integrifolia, T. casaretti & 3,60 & Soares-Silva et al., 1992 \\
\hline E.E. de Assis & M. eleagnoides, $C$. var. venosa, G. polymorpha & 2,93 & Durigan, 1994 \\
\hline E.E. de Marília & C. tomentosum, Nectandra lanceolata, C. fissilis & 3,44 & Durigan, 1994 \\
\hline Faz. Berrante & A. polyneuron, T. claussenu, G. integrifolia & 3.76 & Durigan, 1994 \\
\hline Faz. São Luis & C. canjerana, $P$. rigida, $C$. tomentosum. & 3,74 & Durigan, 1994 \\
\hline
\end{tabular}


grau de preservação da área em estudo e baixa fertilidade e/ou condições de anaerobiose.

\subsubsection{Individuos mortos e ramificados}

Foram consideradas, na amostragem, apenas as árvores mortas encontradas em pé, perfazendo um percentual de 8,60\% (30 árvores) do número total de indivíduos levantados. O maior número de árvores mortas eram de embaúba (Cecropia sp), com diâmetro relativamente grande, o que nos leva a concluir que estas árvores mortas já cumpriram seu papel ou como espécie pioneira ou por serem de uma espécie bastante sensível a geadas. É importante, então, ressaltar que na área de estudo foram registradas geadas em 1994, e a espécie considerada possivelmente tenha morrido devido a tal episódio.

Segundo Leitão Filho et al. (no prelo), é esperado, em floresta em sucessão secundária, que exista um maior número de indivíduos mortos pertencentes aos primeiros estádios sucessionais, o que não é observado em floresta madura, em que o número de árvores mortas deve ser menor e em diferentes estádios sucessionais, a não ser que a floresta esteja em desequilíbrio provocadc por fatores decorrentes de distúrbios.

O percentual encontrado de árvores mortas pode ser considerado alto quando comparado com os valores encontrados por Leitão Filho et al. (no prelo) em uma mata ciliar no rio Mogi Guaçú, próxima à área estudada, que foi de 7,06\% e por Salis (1990), em mata ciliar no município de Brotas, que foi de $6,68 \%$. Isto pode ser explicado devido a um distúrbio recente, em que as árvores, submersas por períodos prolongados, morreram, mas continuaram mantendo-se de pé. Observou-se, ainda, no levantamento, que algumas árvores que, aparentemente, 
estavam mortas, apresentaram brotações novas, mostrando que algumas espécies têm a capacidade de recuperar-se após alguns períodos de distúrbios.

Com relação aos indivíduos ramificados, eles representaram 4,30 \% (15 indivíduos) dos totais amostrados. Mas 2,58 \% (9 indivíduos) encontraram-se abaixo da altura média. Tais dados corroboram com Ewusie (1980), que considera a bifurcação uma característica dos indivíduos dos estratos inferiores das florestas tropicais, e com Costa (1992), que diz que o número de árvores mortas e ramificadas é resultante dos processos naturais da dinâmica de florestas tropicais.

\subsubsection{Levantamento geral para as familias}

Os parâmetros fitossociológicos para as famílias do estrato arbustivoarbóreo estão apresentados em anexo (Apêndice 2), em ordem decrescente de VI (valor de importância), para a mata ciliar estudada.

Pode-se observar, em anexo, que as dez famílias mais importantes com relação ao VI são: Euphorbiaceae (52,74 \%); Melastomataceae (29,57\%); Myrtaceae (24,31\%); Mimosaceae (24,03\%); Lauraceae (21,38\%); Phytolacaceae (21,15\%); Fabaceae (17,64\%); Meliaceae (14,91\%); Flacourtiaceae (12,10\%); e Annonaceae (9,14\%), que juntas, somaram $75,66 \%$ do VI total. Enquanto isso as 10 famílias restantes somaram $24,34 \%$ do VI total.

Com relação ao $\mathrm{VC}$, as dez famílias mais representativas foram: Euphorbiaceae (42,28\%); Melastomataceae (22,59\%); Mimosaceae (18,22\%); Phytolacaceae (16,50\%); Myrtaceae (16,17\%); Lauraceae (15.57\%); Fabaceae (11,82 \%); Meliaceae (9.10\%); Flacourtiaceae (6,28 \%); e Annonaceae (5,65 \%), que juntas, somaram $82,09 \%$ do VI total. Enquanto que as 10 famílias restantes somaram $17,91 \%$ do VI total. 
O decréscimo do VI das 10 famílias mais importantes não foi gradual, mostrando a família Euphorbiaceae predominando o estrato, indicando que a vegetação estudada é caracterizada como de início de sucessão. Estas famílias também ocuparam as 10 primeiras posições no VC (apêndice 2), com inversão de Myrtaceae da terceira posição por Mimosaceae; Mimosaceae da quarta posição por Phytolacaceae; Lauraceae da quinta posição por Myrtaceae; Phytolacaceae da sexta posição por Lauraceae.

A primeira posição em VI ocupada pela família Euphorbiaceae foi devido, principalmente, à contribuição das espécies Sebastiana klotzschiana e Alchornea glandulosa, que apresentaram 42 e 13 indivíduos, respectivamente. Esta família ocupou uma das primeiras posições de VI nos trabalhos de Bertoni 1984; Mencacci \& Schlittler, 1992; Rodrigues, 1991.

A família Melastomataceae foi a segunda família mais importante, principalmente, devido à espécie Miconia langsdorfii que apresentou 50 indivíduos.

A família Myrtacea ocupou a terceira posição no VI, devido a contribuição da espécie Eugenia $s p$. que apresentou 36 indivíduos. Esta família ocupou as primeiras posições em VI no trabalho de Mencacci, 1997.

Se fosse considerado o sistema de classificação de Engler (1954) a família Leguminosa ocuparia a segunda posição, com o valor de VI de $44,67 \%$. VC de 33,15.

\subsubsection{Regeneração natural}

O levantamento florístico da regeneração natural apresentou 77 indivíduos de 20 espécies em outubro de 1995; 105 indivíduos de 21 espécies em abril de 1996; e 129 indivíduos de 22 espécies em outubro de 1996. Os índices de 
diversidade de Shannon foram 2,57; 2,61; e 2,55. A equabilidade ( $J$ ') estimada foi $0,89,0,87$, e 0,85 para o primeiro, segundo e terceiro levantamentos, respectivamente.

Tabela 4 - Lista das espécies amostradas da regeneração natural, nos três levantamentos realizados na mata ciliar do rio Mogi Guaçú, Município de Mogi Guaçú,SP,

\begin{tabular}{lccc}
\hline NOME CIENTÍFICO & $\mathrm{l}^{0}$ Levantamento & $2^{0}$ Levantamento & $3^{0}$ Levantamento \\
\hline Alchornea glandulosa & $\mathrm{X}$ & $\mathrm{X}$ & $\mathrm{X}$ \\
Cariniana legalis & $\mathrm{X}$ & $\mathrm{X}$ & $\mathrm{X}$ \\
Casearia sylvestris & $\mathrm{X}$ & $\mathrm{X}$ & $\mathrm{X}$ \\
Copaifera langsdorffi & $\mathrm{X}$ & $\mathrm{X}$ & $\mathrm{X}$ \\
Cyclolobium vecchi & $\mathrm{X}$ & $\mathrm{X}$ & $\mathrm{X}$ \\
Desconhecida & $\mathrm{X}$ & $\mathrm{X}$ & $\mathrm{X}$ \\
Desconhecida1 & $\mathrm{X}$ & $\mathrm{X}$ & $\mathrm{X}$ \\
Desconhecida2 & $\mathrm{X}$ & $\mathrm{X}$ & $\mathrm{X}$ \\
Duguetia lanceolata & $\mathrm{X}$ & $\mathrm{X}$ & $\mathrm{X}$ \\
Eugenia & $\mathrm{X}$ & $\mathrm{X}$ & $\mathrm{X}$ \\
Gallesia integrifolia & $\mathrm{X}$ & $\mathrm{X}$ & $\mathrm{X}$ \\
Guarea guidonea & $\mathrm{X}$ & $\mathrm{X}$ & $\mathrm{X}$ \\
Inga vera & $\mathrm{X}$ & $\mathrm{X}$ & $\mathrm{X}$ \\
Machaerium brasiliensis & $\mathrm{X}$ & $\mathrm{X}$ & $\mathrm{X}$ \\
Miconia langsdorfii & $\mathrm{X}$ & $\mathrm{X}$ & $\mathrm{X}$ \\
Myrtacea & $\mathrm{X}$ & $\mathrm{X}$ & $\mathrm{X}$ \\
Ocotea & $\mathrm{X}$ & $\mathrm{X}$ & $\mathrm{X}$ \\
Piptadenia gonoacantha & $\mathrm{X}$ & & $\mathrm{X}$ \\
Sebastiana klotzchiana & & $\mathrm{X}$ & $\mathrm{X}$ \\
Syagrus romanzoffiana & & $\mathrm{X}$ & $\mathrm{X}$ \\
Trichilia catigua & $\mathrm{X}$ & $\mathrm{X}$ \\
Trichilia pallida & $\mathrm{X}$ & & \\
\hline
\end{tabular}

Das espécies amostradas, três não foram identificadas em nível de família e três tiveram identificação em nível de família.

A Tabela 5 apresenta, por ordem alfabética, as famílias, as espécies, os nomes vulgares da região (quando disponíveis) e os grupos ecológicos, para a 
Tabela 5 - Lista das famílias e espécies amostradas da regeneração natural na mata ciliar do rio Mogi Guaçú, Município de Mogi Guaçú, SP, em ordem alfabética de famílias, as espécies, acompanhadas de seus nomes vulgares (quando conhecidos), e os grupos ecológicos.

\begin{tabular}{|c|c|c|c|}
\hline FAMIlliA & NOME CIENTÍFICO & NOME & GE (*) \\
\hline Annonoceae & Duguetia lanceolata St. Hil. & Pindaíba & ST \\
\hline Arecaceae & Syagrus romanzoffiana (Cham.) Glassm. & Gerivá & SI \\
\hline Caesalpiniaceae & Copaifera langsdorffi i Desf. & Óleo Copaiba & ST \\
\hline Euphorbiaceae & $\begin{array}{l}\text { Alchornea glandulosa Poepp. \& Endl. } \\
\text { Sebastiana klotzchiana (Muell. Arg.) Muell. Arg. }\end{array}$ & $\begin{array}{l}\text { Tapiá } \\
\text { Sebastiana }\end{array}$ & $\begin{array}{l}\mathbf{P} \\
\mathbf{P}\end{array}$ \\
\hline Fabaceae & $\begin{array}{l}\text { Machaerium brasiliensis Vog } \\
\text { Cyclolobium vecchi A. Samp. ex Hoehne }\end{array}$ & $\begin{array}{l}\text { Machaerium } \\
\text { Louveira }\end{array}$ & $\begin{array}{l}\text { SI } \\
\text { ST }\end{array}$ \\
\hline Flacourtiaceae & Casearia sylvestris Swartz. & Guaçatonga & $\mathbf{P}$ \\
\hline Lauraceae & Ocotea sp. & Canela & SC \\
\hline Lecythidaceae & Cariniana legalis (Mart.) Kuntze & Jequetibá & ST \\
\hline Melastomataceae & Miconia langsdorfii Cogn. & Miconia & $\mathbf{P}$ \\
\hline Meliaceae & $\begin{array}{l}\text { Guarea guidonea (L.)Sleumer. } \\
\text { Trichilia catigua Adr. Juss. } \\
\text { Trichilia pallida Sw. }\end{array}$ & $\begin{array}{l}\text { Marinheiro } \\
\text { Catiguá } \\
\text { Trichila }\end{array}$ & $\begin{array}{l}\text { SI } \\
\text { ST } \\
\text { ST }\end{array}$ \\
\hline Mimosaceae & $\begin{array}{l}\text { Inga vera sub affines. } \\
\text { Piptadenia gonoacantha (Mart.) Macbr. }\end{array}$ & $\begin{array}{l}\text { Inga } \\
\text { Pau-jacaré }\end{array}$ & $\begin{array}{l}\text { SI } \\
\text { SI }\end{array}$ \\
\hline Myrtaceae & $\begin{array}{l}\text { Eugenia sp } \\
\text { Mirtacea }\end{array}$ & $\begin{array}{l}\text { Eugenia } \\
\text { Mirtacea }\end{array}$ & $\begin{array}{l}\text { SC } \\
\text { SC }\end{array}$ \\
\hline Phytolacaceae & Gallesia integrifolia (Spreng.) Harms. & Pau d'alho & ST \\
\hline Indeterminadas & $\begin{array}{l}\text { Desconhecida } \\
\text { Desconhecida } 1 \\
\text { Desconhecida } 2\end{array}$ & & $\begin{array}{l}\text { SC } \\
\text { SC } \\
\text { SC }\end{array}$ \\
\hline
\end{tabular}


regeneração natural,amostradas na mata ciliar do rio Mogi Guaçú, no Município de Mogi Guaçú, Estado de São Paulo.

Com exceção de Trichilia pallida, todas as demais espécies identificadas no estádio de plântulas foram também amostradas no levantamento fitossociológico da flora arbustivo-arbórea.

Como nos mostra a Tabela 5, a família de maior riqueza florística foi Meliaceae, com 3 espécies amostradas, seguida de Euphorbiaceae, fabaceae, Mimosaceae e Myrtaceae com 2 espécies cada. Nas 9 famílias restantes foi amostrada apenas uma espécie de cada.

\subsubsection{Altura da regeneração natural por espécies}

$\mathrm{Na}$ Figura 14, observa-se que as espécies com maior crescimento em altura foram Gallesia integrifolia, Miconia langsdorfii e Duguetia lanceolata, sendo a primeira uma secundária inicial e as duas últimas pioneiras, fato que já era esperado, já que espécies de início de sucessão apresentam um rápido crescimento inicial.

Onde ocorreu crescimento em todos os levantamentos foi somente em Gallesia integrifolia e Machaerium brasiliensis, este último devido ao recrutamento de novos indivíduos desta espécie. Em algumas espécies como Duguetia lanceolata, Guarea guidonea e Cariniana legalis houve crescimento do primeiro levantamento para o segundo e redução do segundo para o terceiro. Essa situação pode ser explicada porque do primeiro para o segundo levantamento foi um período chuvoso e do segundo para o terceiro levantamento foi um período seco.

Em outras espécies como Casearia sylvestris e Eugenia houve redução do primeiro para o segundo levantamento e crescimento para o terceiro. Todos 
estes comportamentos das espécies foram devidos principalmente porque ocorreu morte dos indivíduos amostrados e/ou quebra dos ponteiros. Algurnas espécies não apresentaram crescimento, talvez devido à condição de microclima na qual se encontravam, o qual não era propício para o seu desenvolvimento.

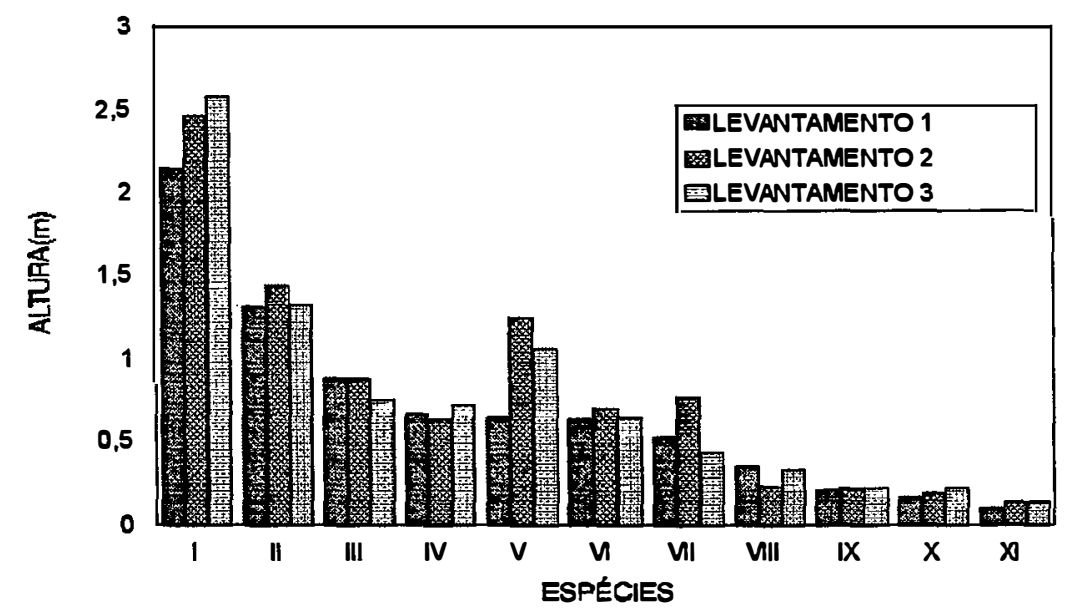

I - Gallesia integrifolia; II - Miconia langsdorfii; III - Duguetia lanceolata; IV - Casearia sylvestris; V Alchornea glandulosa; VI - Cariniana legalis; VII - Guarea guidonea; VIII - Eugenia sp; IX - Inga vera; $\mathrm{X}$ - Machaeri um brasiliensis.

Figura 14 - Altura dos indivíduos, das espécies amostradas, no levantamento da regeneração natural da mata ciliar do rio Mogi Guaçú, Mogi Guaçú SP.

\subsubsection{Número de indivíduos da regeneração natural por espécies}

A espécie mais abundante no primeiro e segundo levantamentos foi Eugenia sp. (Figura 15). Machaerium brasiliensis apresentou um número elevado do primeiro em relação aos outros dois levantamentos, devido à alta recrutação de novos indivíduos. Guarea guidonea e Cyclolobium vecchi apresentaram um decréscimo do primeiro para o segundo levantamento. Gallesia integrifolia 
Miconia langsdorfii e Casearia sylvestris não apresentaram acréscimo no número de indivíduos durante o período de observação. As espécies Alchornea glandulosa e Duguetia lanceolata apresentaram redução do número de indivíduos, devido à morte causada por várias razões, como o pisoteio de animais silvestres de grande porte que ocorrem na área em número bastante elevado, devido, também, a competição por água, luz, nutrientes e espaço físico entre as espécies.

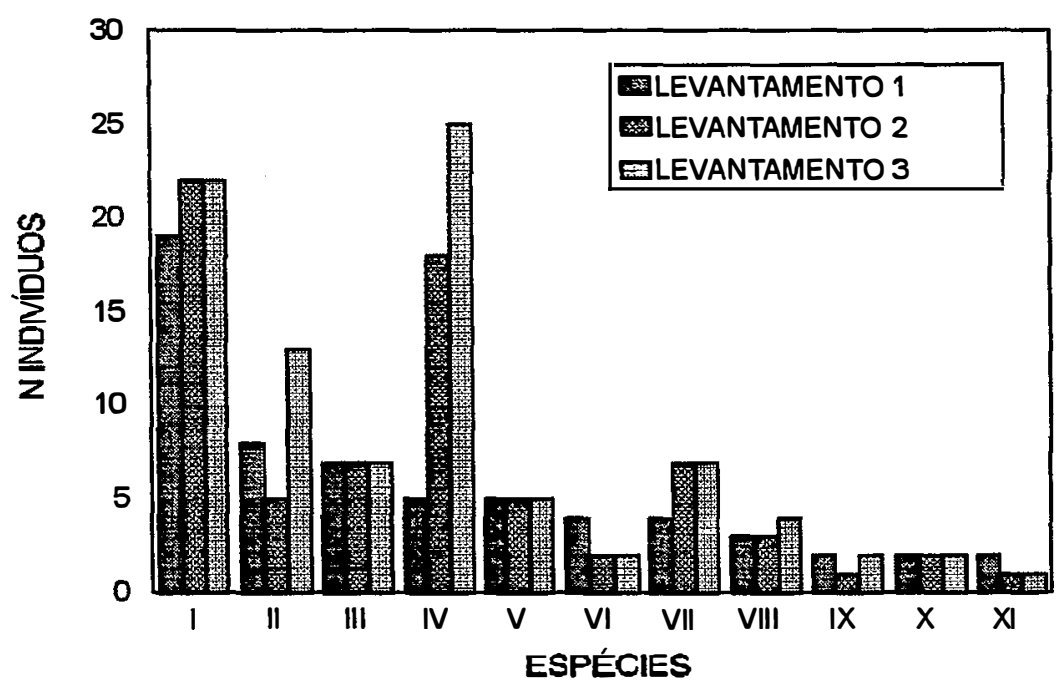

I - Eugenia sp; II - Guarea guidonea; III - Gallesia integrifolia; IV - Machaerium brasiliensis; V Miconia langsdorfii; VI - Alchornea glandulosa; VII - Inga vera; VIII - Cariniana legalis; IX - Casearia sylvestris; X - Duguetia lanceolata; XI - Cyclolobium vecchi.

Figura 15 - Número de indivíduos por espécie amostradas, no levantamento da regeneração natural da mata ciliar do rio Mogi Guaçú, Mogi Guaçú SP

\subsubsection{Número de espécies da regeneração natural por levantamento}

A Figura 16 mostra que no primeiro levantamento foram contabilizadas vinte espécies. Houve um aumento nos levantamentos subsequentes, tanto no 
número de espécies quanto no número de indivíduos. Esta recrutação é observada devido à chuva de sementes e germinação das sementes que estão ocorrendo a todo instante na dinâmica sucessional de maneira natural em uma mata tropical.

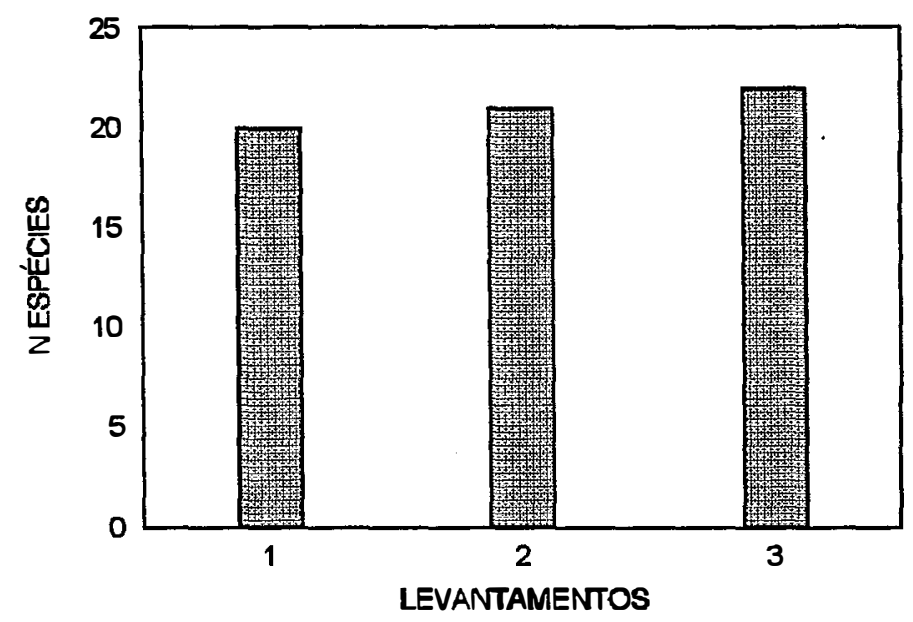

Figura 16 - Número de espécies amostradas, no levantamento da regeneração natural da mata ciliar do rio Mogi Guaçú, Mogi Guaçú - SP

\subsubsection{Número de indivíduos da regeneração natural, por levantamento}

$\mathrm{Na}$ Figura 17 observa-se um aumento gradativo do número de indivíduos no decorrer dos levantamentos, comportamento considerado normal na dinâmica natural de uma floresta tropical, em que indivíduos regeneram em maior número do que morrem com o passar do tempo e, principalmente, com a mudança de estação chuvosa para a época de seca e vice-versa, ou quando ocorre a dispersão dos propágulos, fazendo com que haja a regeneração natural e a formação do banco de plântulas. 


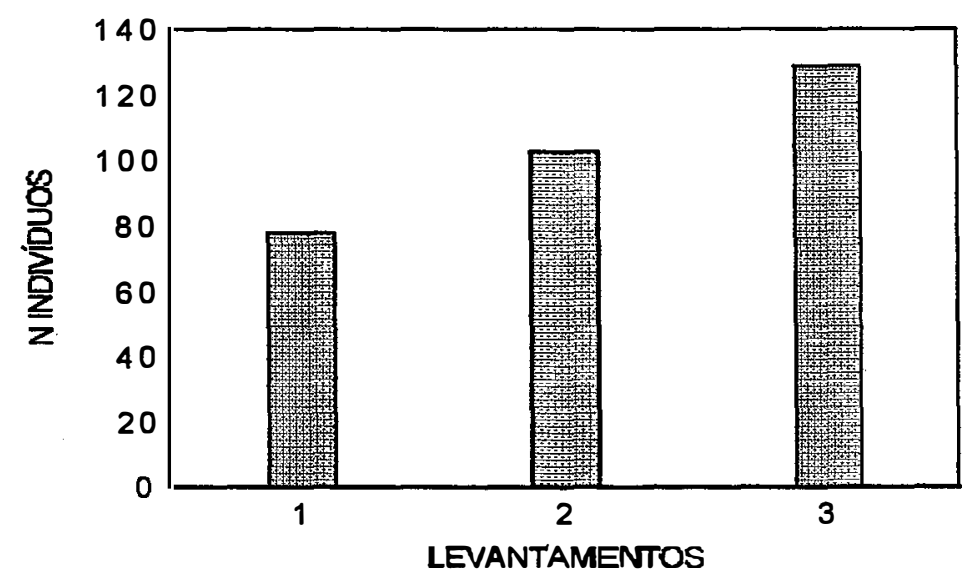

Figura 17 - Número de indivíduos amostrados, no levantamento da regeneração natural da mata ciliar do rio Mogi Guaçú, Mogi Guaçú - SP

\subsubsection{5 Índice de diversidade da regeneração natural por levantamento}

Através da Figura 18, verificamos que o índice de diversidade é baixo, e semelhante nos três levantamentos, indicando uma colonização pouco diversificada, o que poderá ocorrer em uma baixa diversidade na população de adultos no futuro.

A justificativa refere-se ao fato de a mata se encontrar em condições de anaerobiose, ou baixa fertilidade, ou competição das plântulas, ou mesmo alelopatia intraespecífica das espécies. Martins (1979) afirma que os índices de diversidade de espécies arbóreas são menores nas florestas sobre solos com baixa fertilidade e/ou anaerobiose, como ocorre em matas ciliares e de várzeas, ou porque a maioria das espécies tropicais existe em baixa densidade.

Essa baixa diversidade também pode estar relacionada às geadas ou a seca prolongada,este último período ocorrendo nos meses de junho, julho e 
agosto,

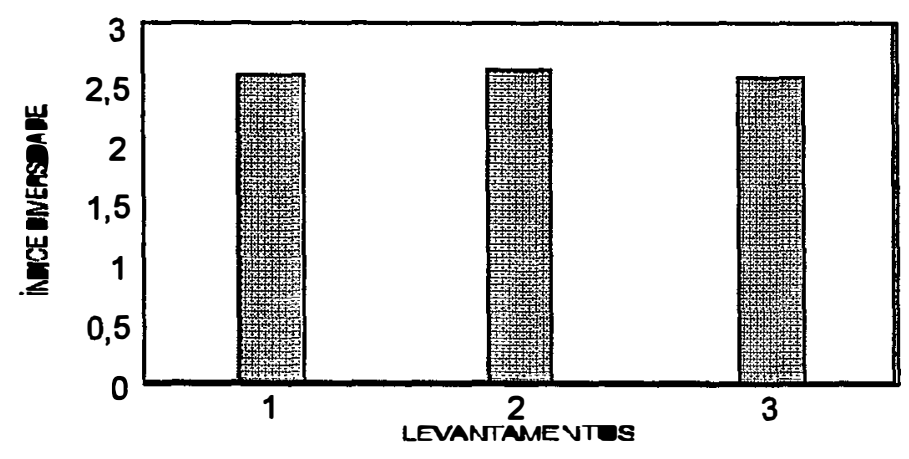

Figura 18 - Índice de diversidade para a regeneração natural da mata ciliar do rio Mogi Guaçú, Mogi Guaçú - SP

como no ano de 1994, e que não foi detectada neste estudo porque o nosso primeiro levantamento ocorreu apenas em outubro daquele ano. Sabe-se, no entanto, que a ocorrência de geadas influencia negativamente na germinação de algumas espécies altamentes sensíveis. Desta maneira, a ocorrência de mortalidade e fatores adversos à germinação contribuíram para o baixo índice de diversidade.

\subsubsection{Número de espécies da regeneração natural, por categorias sucessionais.}

O conceito de floresta clímax está sendo revisto e atualmente a floresta está sendo vista como um conjunto de manchas em diferentes estádios sucessionais, formando um mosaico em constante transformação (Gandolfi, 1991). 
De maneira geral, os pesquisadores estão dando mais ênfase aos aspectos sucessionais das espécies, buscando o maior número de informações, para que se possa entender melhor a dinâmica sucessional.

Quando foi considerada a relação entre as espécies amostradas na mata ciliar do rio Mogi Guaçú e suas categorias sucessionais, observou-se um grande equilíbrio entre as categorias. As espécies secundárias tardias contribuíram com

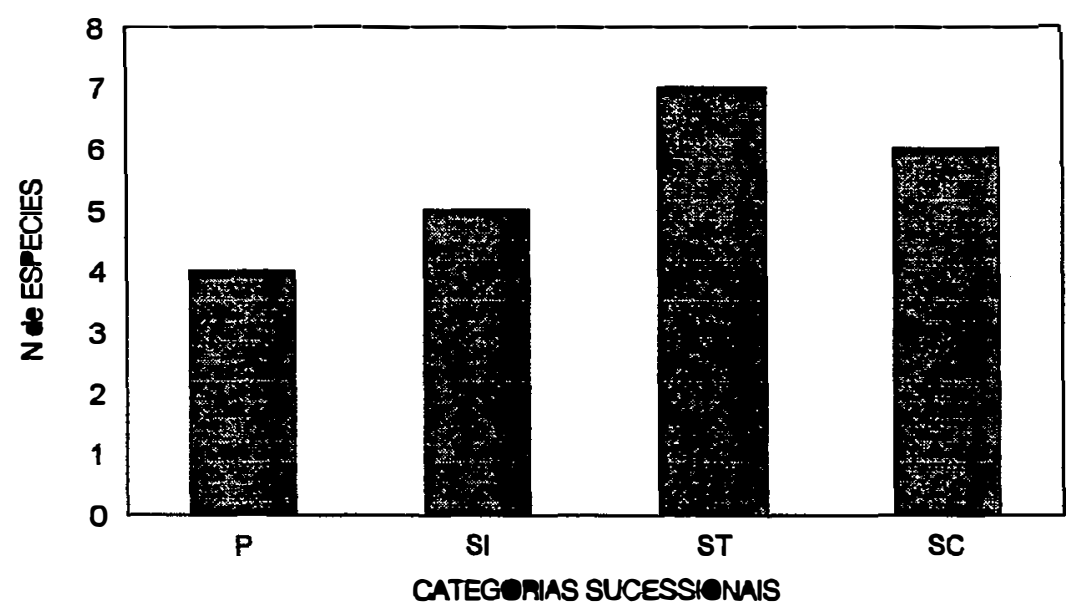

Figura 19 - Classificação sucessional de espécies, por grupo ecológico, para a regeneração natural da mata ciliar do rio Mogi Guaçú, Mogi Guaçú SP.

$31,27 \%$ do total; as espécies sem caracterização com 27,27\%; as secundárias iniciais com $22,73 \%$; e as pioneiras com $18,18 \%$. No entant, vale ressaltar que as espécies sem caracterização representam um alta porcentagem que poderia modificar os resultados para os diferentes grupos sucessionais se efetivamente pertencessem integralmente a algumas das outras categorias sucessionais. 
O fato de termos amostrado plântulas das espécies dos estratos superiores, principalmente aqueles dos estádios finais da sucessão, leva-nos a concluir que, na dinâmica dessa formação florestal, a reposição de indivíduos está ocorrendo naturalmente e que a mata se apresenta sem a ocorrência de perturbações antrópicas recentes.

\subsubsection{Relações interespecíficas}

Analisando as relações intraespecíficas nas parcelas, foi possível observar correlações positivas significativas entre a abundância dos indivíduos da regeneração de $M$. langsdorfii com abundância dos indivíduos da regeneração de G. integrifolia; a abundância dos indivíduos da regeneração de G. guidonea com a área basal dos indivíduos adultos de $S$. romanzoffiana; a abundância dos indivíduos da regeneração de $S$. romanzoffiana com a área basal dos indivíduos adultos de $S$. romanzoffiana; a área basal dos indivíduos adultos de $M$. langsdorfii com abundância dos indivíduos adultos de $M$. langsdorfii; a área basal dos indivíduos adultos de $G$. integrifolia com a abundância de indivíduos adultos de G. integrifolia; área basal dos indivíduos adultos de $I$. vera com a abundância de indivíduos adultos de $I$. vera e com a abundância dos indivíduos adultos de $G$. guidonea; a área basal dos indivíduos adultos de G. guidonea com a abundância dos indivíduos adultos de G. guidonea; a área basal dos indivíduos adultos de $S$. romanzoffiana com a abundância dos indivíduos adultos de $S$. romanzoffiana, sendo esta última a mais forte correlação observada $(r=0.993)($ Tabela 6).

A observação de uma forte correlação positiva entre a área basal dos indivíduos adultos de $S$. romanzoffiana com a abundância dos indivíduos adultos de $S$. romanzoffiana, parece estar relacionada, principalmente, ao padrão de dispersão de sementes e a formação do banco de plântulas apresentado pela 
Tabela 6: Coeficiente de correlação de Spearnan ${ }^{\circledR}$ entre a abundância de indivíduos da regeneração, área basal dos indivíduos adultos e a abundância de indivíduos adultos por hectare.

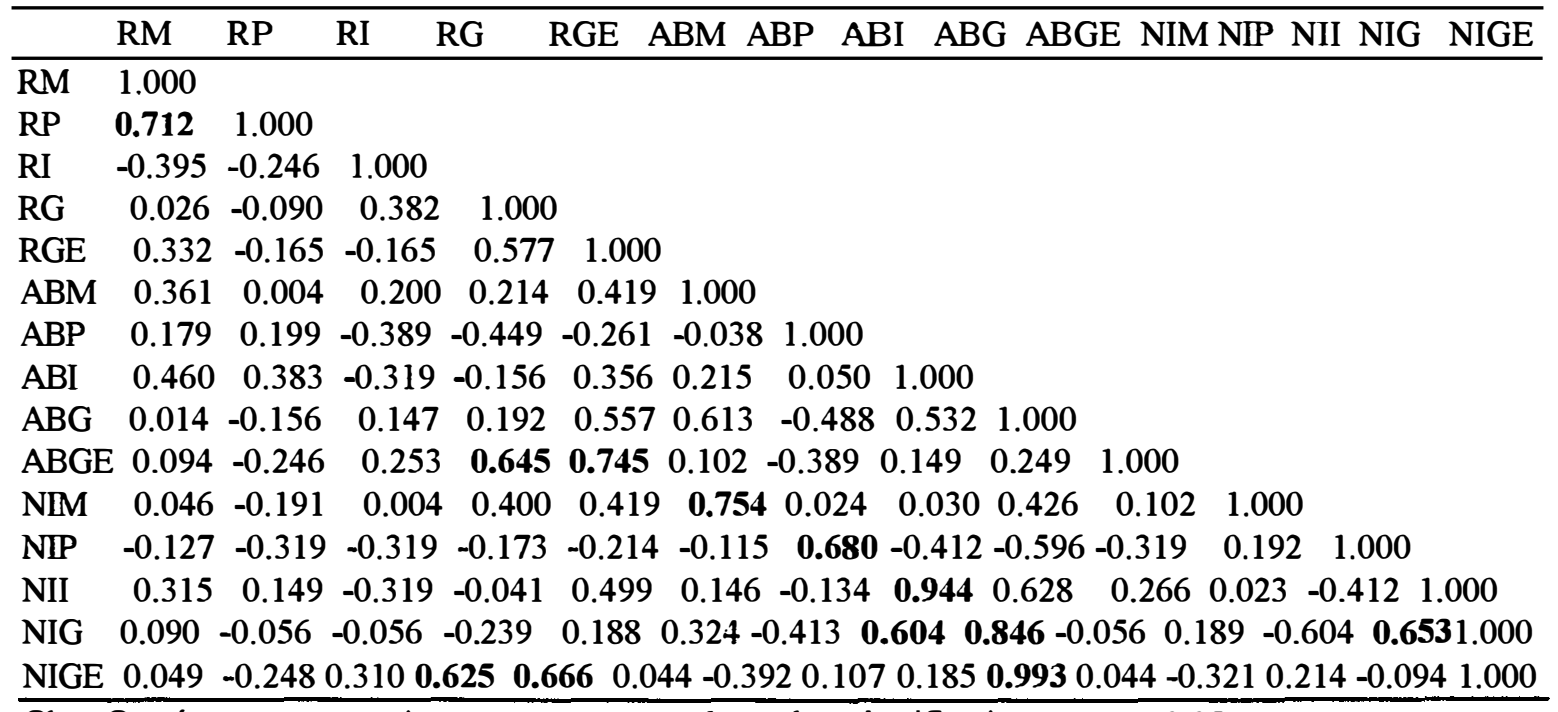

Obs.: Os números em negrito representam os valores de $r$ significativos para $p<0,05$.

Onde : $\mathrm{RM}=$ regeneração da espécie $M$. langsdorfii;

$\mathrm{RP}=$ regeneração da espécie G.integrifolia;

$\mathrm{RI}=$ regeneração da espécie $I$. vera;

$\mathrm{RG}=$ regeneração da espécie $G$. guidonea;

$\mathrm{RGE}=$ regeneração da espécie $S$. romanzoffiana;

$\mathrm{ABM}=$ Área basal da espécie $M$. langsdorfii;

$\mathrm{ABP}=$ Área basal da espécie G.integrifolia;

$\mathrm{ABI}=$ Área basal da espécie $I$. vera;

$\mathrm{ABG}=$ Área basal da espécie G. guidonea;

ABGE = Área basal da espécie $S$. romanzoffiana;

NIM = Número de indivíduos da espécie $M$. langsdorfii;

NIP = Número de indivíduos da espécie G.integrifolia;

NII = Número de indivíduos da espécie $I$. vera;

NIG = Número de indivíduos da espécie G. guidonea;

NIGE = Número de indivíduos da espécie $S$. romanzoffiana . 
espécie.

$\mathrm{O}$ teste de correlação entre a área basal dos indivíduos adultos e a abundância dos indivíduos da regeneração de todas as espécies estudadas mostrounos uma correlação positiva significativa, podendo indicar que, em parcelas onde há um maior número de indivíduos adultos, existe um ambiente mais favorável ao estabelecimento da regeneração.

A correlação negativa que foi observada entre as espécies sugere a existência de efeitos dependentes da distância, produzindo mortalidade de plântulas ou inviabilidade de sementes próximo às plantas. Vários fatores podem estar causando essa correlação negativa, como ataque de patógenos e herbívoros, predação, alelopatia intraespecífica, competição por nutrientes e luz (Clark \& Clark, 1984; Augspurger, 1984).

Considerando que existe uma heterogeneidade ambiental na área estudada e que as espécies analisadas neste estudo são classificadas como pertencentes a diferentes grupos ecológicos e, por esta razão, devem responder de maneira diferenciada às condições ambientais, é de esperar que haja diferenças no estabelecimento espacial e no crescimento dos indivíduos destas espécies. Cabe ressaltar que no ano de 1994 ocorreu um período em que foram observadas geadas bastante drásticas e uma seca prolongada, episódio, aliás, que causou morte dos indivíduos adultos e que, com certeza, prejudicou a regeneração natural das espécies, por ser mais sensível a mudanças bruscas de temperatura.

Estudos repetidos a longo prazo, analisando a mortalidade, o crescimento e a reprodução dos indivíduos, são fundamentais para se fazer qualquer inferência a respeito da manutenção de estabilidade de espécies arbóreas tropicais. 


\section{CONCLUSÕES}

A mata ciliar apresentou boa diversidade florística. A família Euphorbiaceae apresentou a maior riqueza de espécies, o maior valor de importância e o maior valor de cobertura, sendo também a família mais abundante, dominante e freqüente da amostragem.

Quanto às espécies, Sebastiana klotzchiana foi a que teve maior valor de importância, ocupando a primeira posição quanto à distribuição, sendo superada por Miconia langsdorfii em valor de cobertura, pela biomassa e número de indivíduos. Estas espécies são classificadas como pioneiras, caracterizando a mata como de início de sucessão.

O grande predomínio de espécies pioneiras no estrato arbóreo-arbustivo sugere o grau elevado de perturbações que ocorreu devido ao histórico de perturbações recentes (corte seletivo das espécies) e as inundações periódicas e prolongadas, que são provocadas pelo desmatamento que ocorre ao longo dos leitos dos rios que permite com que se aumente a velocidade das enxurradas, ocasionando, assim, a lavagem da serapilheira.

A análise da regeneração natural sugere que a mata estudada se apresenta em processo de dinâmica sucessional devido, principalmente, à presença de espécies de final de sucessão que ocorreram em maior número.

Todas as espécies arbóreas amostradas apresentaram exemplares na regeneração natural, indicando que, no futuro, tais espécies deverão estar presentes no estrato da mata ciliar estuda. 
A diversidade florística da regeneração natural por levantamento foi considerada baixa. Machaerium brasiliensis foi a espécie que apresentou maior número de indivíduos. Gallesia integrifolia apresentou o maior crescimento em altura.

Faz se necessário um estudo multidisciplinar das características físicas do solo da mata ciliar, topografia, nível de influência do rio, para que se possa delimitar melhor o ambiente físico da mata ciliar e caracterizar melhor os microambientes de futuros estudos.

É necessário o estudo de dinâmica de clareiras e dinâmica de comunidades de plantas para se entender melhor a regeneração natural das espécies arbóreas.

Deve-se realizar uma análise profunda e a longo prazo sobre as espécies arbóreas tropicais, abordando os processos dinâmicos, tanto de indivíduos adultos como jovens. Estudando a dispersão de propágulos, polinizadores e dispersores, germinação e o estabelecimento de plântulas, que são parâmetros de vital importância para se fazer qualquer inferência a respeito da dinâmica sucessional, tomada de decisão ou preservação dos remanescentes florestais, da manutenção e da estabilidade de espécies arbóreas tropicais. 


\section{REFERÊNCIAS BIBLIOGRÁFICAS}

AB'SABER, A. Contribuição à geomorfologia da área dos cerrados. In: SIMPÓSIO SOBRE O CERRADO, São Paulo, 1971. São Paulo: Edgard Blücher; EDUSP, 1971. p.97-103.

AUBREVILLE, A. La forêt coloniale: Les forêts d'Afrique équatoriale. Bois et Foréts Tropical, v.2, p. 24-35, 1938.

AUGSPURGER, C.K. Seedling survival of tropical tree species: interactions of dispersal distance, light-gaps, and pathogens. Ecology, v.65, p.1705-1712, 1984.

BARBOSA, L.M.; ASPERTI, L.M.; BEDINELLI, C. et al. Estudos sobre o estabelecimento e desenvolvimento de espécies com ampla ocorrência em mata ciliar. In: CONGRESSO NACIONAL SOBRE ESSÊNCIAS NATIVAS., 2, São Paulo, 1992 Anais. Silvicultura ém São Paulo, v.16A, pt.1, p.605-608, 1992.

BATISTA, E.A. Levantamentos fitossociológicos aplicados à vegetação de cerrado; utilizando-se de fotografias aéreas verticais. Piracicaba, 1982. 76p. Dissertação (Mestrado) - Escola Superior de Agricultura "Luiz de Queiroz", Universidade de São Paulo.

BAZZAZ, F.A.; PICKETT, S.T.A. Physiological ecology of tropical succession: a comparative review. Annual Review of ecology and systematics, v.11, p.287$310,1980$.

BERNACCI, L.C. Composição florística da floresta ripária em 15 fragmentos ao longo do rio Jacaré-Pepira, SP. In: CONGRESSO NACIONAL DE BOTÂNICA, 46., Ribeirão Preto 1995. Resumos. Ribeirão Preto: SBB, 1995. p.326.

BERTONI, J.E.A. Composição florística e estrutura fitossociológica de uma 
floresta no interior do Estado de São Paulo: Reserva Estadual de Porto Ferreira. Campinas, 1984. 96p. Dissertação (Mestrado) - Instituto de Biociências, Universidade Estadual de Campinas.

BERTONI, J.E.A.; STUBBLEBINE, W.H.; MARTINS, F.R. et al. Nota prévia: comparação fitossociológica das principais espécies de florestas de terra firme e de várzea na Reserva Estadual de Porto Ferreira (SP). Silvicultura em São Paulo, v.16A, n.1, p.563-571, 1982.

BRASIL. Ministério de Agricultura. Centro Nacional de Ensino e Pesquisas Agronômicas. Levantamento de reconhecimento dos solos do Estado de São Paulo. Rio de janeiro,1960.634p. (Boletim do Serviço Nacional de Pesquisas Agronômicas, 12).

BROKAW, N.V.L. Gap-phase regeneration in a tropical rain forest. Ecology, v.66, p.628-687, 1985.

BUDOWSKI, G. Distribution of tropical american rain forest species in the light of successional process. Turrialba, v.15, n.1, p.40-42, 1965.

BURTON, T.M.; LIKENS, G.E. The effect of strip-cutting on stream temperatures in the Hubbard Brook experimental forest, New Hampshire. Bioscience, v.23, p.433-435, 1973.

CARVALHO, J.C. Florestas nacionais e reservas extrativistas em um modelo de uso sustentado. Brasil Florestal, v.17, n. 69, p. 411990.

CATHARINO, E.L.M. Florística de matas ciliares. In: SIMPÓSIO SOBRE MATA CILIAR, 1., São Paulo, 1989. Anais. São Paulo: Fundação Cargill , 1989. p.61-70.

CLARK, D.A.; CLARK, D.B. Spacing dynamics of a tropical rain forest tree: evaluation of the Janzen-Connel model. American Naturalist, v124, p.769$788,1984$.

CONSELHO ESTADUAL DO MEIO AMBIENTE. Áreas naturais do Estado de São Paulo. São Paulo, 1985. 16p.

COSTA, L.G.S. Estrutura e dinâmica de trecho de mata mesófila semidecídua, na Estação Ecológica de Ibicatú, Piracicaba, SP. São Paulo, 1992. 171p. 
Dissertação (Mestrado) - Instituto de Biociências, Universidade de São Paulo.

CROCHER, W. Life-span of seeds. Botanical Review, v. 4, p.235-274, 1938.

CRONQUIST, A. An integrated system of classification of flowering plants. New York: Columbia University, 1981. 1262p.

DENSLOW, J.S. Patterns of species diversity during succesion under different disturbamce regimes. Oecologia, v.46, p.18-21, 1980.

DURIGAN, G. Florística, fitossociologia e produção de folhedo em matas ciliares da região oeste do Estado de São Paulo. Campinas, 1994. 138p. Tese (Doutorado). - Instituto de Biologia, Universidade Estadual de Campinas.

DURIGAN, G.; DIAS, H.C.S. Abundância e diversidade da regeneração natural sob mata ciliar implantada. In: CONGRESSO FLORESTAL BRASILEIRO, 6., Campos do Jordão, 1990. Anais. Campos do Jordão: s.ed., 1990. p.308312.

DURIGAN, G.; GARRIDO, M.A.O. Fitossociologia de uma mata ciliar remanescente no Município de Assis - S.P. In: CONGRESSO FLORESTAL BRASILEIRO, 6., Campos do Jordão, 1990. Anais. Campos do Jordão: s.ed., 1990. p.113-118.

EWUSIE, J. Y. Elements of tropical ecology. London: Heinemann Educational Books, 1980. 205p.

FINOL, U.H. Nuevos parámetros a considerarse en el analisis estrutural de las selvas virgenes tropicales. Revista Forestal Venezolana, v.14, n.21, p.29-42, 1971.

FINOL, U.H. La silvicultura en la orinoguia venezolana. Revista Forestal Venezolana, v.18, n.25, p.37-114, 1975.

FONSECA, G.A.B. Biogeografia insular aplicada à conservação. Revista Brasileira de Geografia, v.43, n.3, p. 383-388, 1981.

FONSECA, G.A.B.; REDFORD, K.H. The mamal of IBGE's Ecological reserve, Brasília, an analysis of the role of gallery forest in increasing diversity. Revista Brasileira de Biologia, v.44, p.517-523, 1984. 
GABRIEL, J.L.C. Florística, fitossociologia de espécies lenhosas e aspectos da ciclagem de nutrientes em floresta mesófila semidecídua nos municípios de Anhembi e Bofete, SP. Rio Claro, 1997. 179p. Tese (Doutorado). - Instituto de Biociências, Universidade Estadual Paulista.

GANDOLFI, S. Estudo florístico e fitossociológico de uma floresta residual na área do Aeroporto Internacional de São Paulo, Município de Guanulhos, S.P. Campinas, 1991. 232p. Dissertação (Mestrado). - Instituto de Biologia, Universidade Estadual de Campinas.

GANDOLFI, S.; LEITÃO FILHO, H.F; BEZERRA, C.L.F. Levantamento florístico e fitossociológico das espécies arbustivo-arbóreas de uma floresta mesófila semidecídua no município de Guarulhos, S.P. Revista Brasileira de Biologia, v.55, p.753-767, 1995.

GIANOTTI, E. Composição florística e estrutura fitossociológica da vegetação de cerrado e de transição entre cerrado e mata ciliar da Estação Experimental de Itirapina. Campinas, 1988. 213p. Dissertação (Mestrado) - Instituto de Biologia, Universidade Estadual de Campinas.

GIBBS, B.E.; LEITÃO FILHO, H.F. Floristic composition of an area of gallery forest near Mogi-Guaçú, state of São Paulo, S.E. Brazil. Revista Brasileira de Botânica, v.1, n.2, p.151-156. 1978.

GIBBS, B.E.; LEITÃO FILHO, H.F.; ABBOTT, R.J. Aplication of the pointcentred quarter method in a florist survey of an area of gallery forest at MogiGuaçú, SP, Brazil. Revista Brasileira de Botânica. v.3, n.1/3, p.17-22, 1980.

GOMEZ-POMPA, L.F. Posible papel de la vegetación secundária en la evolución de la flora tropical. Biotrópica. v.3, n.2, 125-135, 1971.

HARPER, J.L. Population biology of plants. London: Academic Press. 1977.892p.

HUECK, K. As florestas da América do Sul: ecologia, composição e importância econômica. São Paulo: Polígono; EDUSP, 1972. 466p.

IMAÑA-ENCINAS, J.; PAULA, J.E.; PEREIRA, B.A.S. Fitossociologia dos indivíduos jovens da mata ciliar do córrego Capãozinho. Revista Árvore, v.19, n.2, p.157-170, 1995. 
JANZEN, D.H. Ecologia vegetal nos trópicos. São Paulo: EDUSP, 1980. 79p. (Coleção Temas em Biologia, v.7)

JOLY, C.A. Heterogeneidade ambiental e diversidade de estratégias adaptativas de espécies arbóreas de mata de galeria. In: SIMPÓSIO ANUAL DA ACIESP, 10.,b São Paulo, 1986. Anais. São Paulo: ACIESP, 1986. p.19-38.

JONG VAN LIER, Q.; DOURADO NETO, D. Balanço Hídrico: versão 3.21. Piracicaba: ESALQ, Depto de Agricultura, 1992.

KOTCHETKOFF-HENRIQUES, O. Composição florística e estrutura fitossociólogica de uma mata semidecídua na cabeceira do Rio Cachoeira, Serra do Itaqueri, Itirapina. Campinas, 1989. 121p. Dissertação (Mestrado) Instituto de Biologia, Universidade Estadual de Campinas.

KOTCHETKOFF-HENRIQUES, O.; PAGANO, S.N. Estudo florístico e fitossociológico em mata mesófila semidecídua da Serra do Itaqueri, Itirapina, Estado de São Paulo, Brasil. Revista Brasileira de Botãnica, v.54, n.3, p.477-487, 1994.

LEITÃO FILHO, H.F. Aspectos taxonômicos das florestas do Estado de São Paulo. In: CONGRESSO NACIONAL SOBRE ESSÊNCIAS NATIVAS, 1., Campos do Jordão.1982. Anais. Silvicultura em São Paulo, v.16A, pt.1, p.197206, 1982.

LEITÃO FILHO, H F; AZEVEDO, D.B.; SANTIN, D.A. et al. Estudos de ecologia da mata ciliar dos rios Mogi Guaçú e Peixe, Mogi Guaçú, SP. Hoehnea, (No prelo).

LIMA, W.P. Função hidrológica da mata ciliar. In: SIMPÓSIO SOBRE MATA CILIAR, 1., São Paulo, 1989. Anais. São Paulo: Fundação Cargill, 1989. p.2542.

LONGO, A.N.; WEBER, O.L.; STEINBACH, F. Análise da regeneração natural da mata atlântica no sul do município de Blumenau. In: CONGRESSO FLORESTAL BRASILEIRO, 7, Anais, 1993. p.316 -318.

MANTOVANI, W. Conceituação e fatores condicionantes. In: SIMPÓSIO SOBRE MATA CILIAR, 1., São Paulo, 1989. Anais. São Paulo: Fundação Cargill, 1989. p.11-19. 
MANTOVANI, W. Estrutura e dinâmica da Floresta Atlântica na Juréia, IguapeSP. São Paulo, 1993. 136p. Tese (Livre Docência) - Instituto de Biociências, Universidade de São Paulo.

MANTOVANI, W.; CATHARINO, E.L.M. Florísitica e fitossociologia. In: KAGEYAMA, P.Y. (Coord). Estudo para implantação de matas ciliares de proteção na Bacia Hidrográfica do Passa Cinco, visando a utilização para abastecimento público. Piracicaba: Convênio DAEE;USP;FEALQ, 1986. 235p. (Relatório de Pesquisa).

MANTOVANI, W.; ROSSI, L.; ROMANIUC NETO, S. et al. Estudo fitossociológico de áreas de mata ciliar em Mogi Guaçú, SP, Brasil. In: SIMPÓSIO SOBRE MATA CILIAR, 1., São Paulo, 1989. Anais. São Paulo: Fundação Cargill, 1989. p.235-267.

MARCHIORI, A.C.C. Levantamento fitossociológico de mata ripária residual do viveiro experimental da FCAVS - UNESP. http://www.bdt.org.br/bdt/ciliar (27 jun 1997).

MARINHO FILHO, J.S.; REIS, M.L. A fauna de mamíferos associada às matas ciliares. In: SIMPÓSIO SOBRE MATA CILIAR, 1., São Paulo, 1989. Anais. São Paulo: Fundação Cargill , 1989. p.43-60.

MARQUES, J.Q., BERTONI, J.; BARRETO, G.B. As perdas por erosão no Estado de São Paulo. Bragantina, v.20, n.47, p. 1143-1181, 1961.

MARTINS, F.R. O método dos quadrantes e a fitossociologia de uma floresta residual do interior do Estado de São Paulo: Parque Estadual de Vaçununga, SP. São Paulo, 1979. 239p. Tese (Doutorado) - Instituto de Biociências, Universidade de São Paulo,

MARTINS NETTO, D.A. Aspectos demográfico de quatro espécies florestais na mata de galeria da reserva genética do Tamanduá, Distrito Federal. In: CONGRESSO FLORESTAL BRASILEIRO, 7., Campos do Jordão, 1993. Anais. Campos do Jordão: s.ed., 1993. p.325-328.

MARTÍNEZ-RAMOS, M. Claros, ciclos vitales de los árboles tropicales y regeneración natural de las selvas altas perenifolias. In: GOMEZ-POMPA, A.; DEL AMO, S. Investigaciones sobre la regeneración de selvas altas en Veracruz. México:Ed. Alhambra Mexicana, 1985. v.2, p.191-239. 
MAZZONI-VIVEIROS, S.C.; LUCHI, A.E. Adaptações Anatômicas. In: SIMPÓSIO SOBRE MATA CILIAR, 1., São Paulo, 1989. Anais. São Paulo: Fundação Cargill , 1989. p.71-87.

MENCACCI, P.C. Algumas características fitossociológicas da composição da comunidade árborea ocorrente na mata ciliar do Ribeirão Claro. http://www.bdt.org.br/bdt/ciliar (27 jun 1997).

MENCACCI, P.C.; SCHLITTLER, F.H.M. Fitossociologia da vegetação arbórea da mata ciliar do Ribeirão Claro, Município de Rio Claro - SP. In: CONGRESSO NACIONAL SOBRE ESSÊNCIAS NATIVAS, 2., São Paulo, 1992. Anais. São Paulo: Instituto Florestal, 1992. p.245-251.

NICOLINI-GABRIEL, E.M. ; PAGANO, S.N. Estrutura fitossociológica do estrato arbóreo de floresta mesófila semidecídua, no município de Jahu, S.P. Arquivos de Biologia e Tecnologia, v.36, n.1, p.165-184. 1993.

OLDEMAN, R.A.A. Tropical rain forest architecture, silvagenesis and diversity. In: SUTTON, S.C.; WHITMORE, T.C.; CHDWICK, A.C. (Ed) Tropical rain forest: ecology and management Oxford: Blackwell Scientific,1989. p.139150. (British Ecological Society, 2).

OLIVEIRA-FILHO, A.T. Composição florística e estrutura comunitária da floresta de galeria do Córrego da Paciência, Cuiabá, MT. Acta Botânica Brasílica, v.3, n.11, p.91-112. 1989.

OLIVEIRA-FILHO, A.T.; ALMEIDA, R.J.; MELLO, J.M. et al. Estrutura fitossociologica e variáveis ambientais em um trecho de mata ciliar do Córrego dos Vilas Boas. Reserva Biológica do Poço Bonito, Lavras-MG. Revista Brasileira de Botânica, v.17, n.1, p.67-85, 1994.

PETERJOHN, W.T.; CORREL, D.L. Nutrient dynamics in an agricultural watershed: observations on the role of a riparian forest. Ecology, v.65, n.5, p.1466-1475, May 1984.

POGGIANI, F. Estrutura, funcionamento e classificação das florestas: implicação ecológica das florestas plantadas. Documentos Florestais, n. 3, p. 9-14, 1989.

PETIT, P.M. Resultados preliminares de unos estudios sobre la regeneración natural espontanea el Bosque "El Caimital". Revista Forestal Venezolana, 
v.12, n.18, p.9-21, 1969.

PINTO, M.M.; DEMATTE, M.E.S.P.; MANTOVANI, W. Estudo fitossociológico em mata mesófila semidecídua residual, no município de Jaboticabal. São Paulo In: CONGRESSO NACIONAL DE BOTÂNICA, 41., Fortaleza, 1990. Resumos.Campinas p.230

RODRIGUES, R.R. Análise de um remanescente de vegetação natural às margens do Rio Passa Cinco, Ipeúna, SP. Campinas, 1991. 325p. Tese (Doutorado) Instituto de Biologia, Universidade Estadual de Campinas.

ROLLET, B. Arquitetura e crescimento das florestas tropicais. Belém: SUDAN, 1978. 22p.

ROZZA, A.F.; RIBEIRO, C.A. Estudo florísitico e fitossociológico de fragmentos de mata ciliar do Campus da ESALQ, Piracicaba, São Paulo. In: CONGRESSO DA SOCIEDADE BOTÂNICA DO ESTADO DE SÃO PAULO, 8., Campinas, 1990. Anais.Campinas: SBSP, 1990. p.7-12.

SALIS, S.M. Composição florística e estrutura de um remanescente de mata ciliar do Rio Jacaré-Pepira, Brotas (SP). Campinas, 1990. 111p. Dissertação (Mestrado) - Instituto de Biologia, Universidade Estadual de Campinas.

SANCHEZ, M. Florística e fitossociologia da vegetação arbórea nas margens do Rio da Fazenda (Parque Estadual da Serra do Mar) - Núcleo Picinguaba Ubatuba - SP. Rio Claro, 1994. 75p. Dissertação (Mestrado) - Instituto de Biociências, Universidade Estadual Paulista "Júlio de Mesquita Filho".

SANCHEZ, M.; PEDRONI,F.; LEITÃO FILHO, H. et al. A vegetação ripária na Mata Atlântica. In: CONGRESSO NACIONAL DE BOTÂNICA, 46., Ribeirão Preto 1995. Resumos. Ribeirão Preto: SBB, 1995. p.322.

SAS INSTITUTE. SAS user`s guide: statistics; version 5. Cary. 1985. 995p.

SOARES-SILVA, L.H.; BIANCHINI, E.; FONSECA, E.P.; et al. Composição florística e fitossociologia do componente arbóreo das florestas ciliares da bacia do rio Tibagi.1. Fazenda Doralice, Ibiporã, PR. In: CONGRESSO NACIONAL SOBRE ESSÊNCIAS NATIVAS, 4., São Paulo, 1992. Anais. São Paulo: Instituto Florestal, 1992. p.199-206. 
SOLBRIG, J.W. Demography and natural selection. In: SOLGRIG, O.T. (Ed.). Demography and evolution in plant populations. University of California Press; Blackwell Scientific, (Botanical Monographs).

STEINBLUMS, I.J; FROELICH, H.A.; LYONS, J.K. Designing stable buffer strips for stream protection. Journal of Forestry. v.82, n. 1, p.49-52, 1984.

THORNTHWAITE, C.W.; MATTER, J.R. The water balance. Publications in climatology, 1955.

VIANA, V.M. Seed and seedling availability as a basis for managements of natural forest regeneration. In: ANDERSON; A.B. (Ed.) Alternatives to deforestation: steps toward sustainable use of amazon rain forest. Columbia University Press, 1990. p.99-115.

WATT, A.S. Pattern and process in plant comunity. Journal of Ecology, v.35, p.1-22, 1947.

WHITMORE, T.C. Tropical rain forest of the Ear East. Oxford: Clarendon Press, 1975. 282p.

WHITMORE, T.C. On pattern and process in forests. In: NEWMAN, E. I. (Ed.) The plant community as a working mechanism. Oxford: Blackwell Scientific, 1983. p.45-69. (British Ecological Society, 2).

ZIPPARRO, V.B.; SCHLITTLER, F.H. M. Estrutura da vegetação arbórea na mata ciliar do ribeirão Claro, Município de Rio Claro - SP. In: CONGRESSO NACIONAL SOBRE ESSÊNCIAS NATIVAS, 2., São Paulo,1992. Anais. São Paulo: Instituto Florestal, 1992. p.212-218. 
APÊNDICE 1 Parâmetros fitossociológicos das espécies presentes na mata ciliar da Estação Ecológica de Mogi Guaçú, Mogi Guaçú - SP., em ordem decrescente de VI = valor de importância; $N^{\circ}$ Ind = número de indivíduos; $\mathrm{N}^{\circ} \mathrm{Parc}=$ número de parcelas presentes; $\mathrm{DoA}=$ dominância absoluta; $\mathrm{DoR}=$ dominância relativa; $\mathrm{DA}=$ densidade absoluta; $\mathrm{DR}=$ densidade relativa; $\mathrm{FA}=$ frequência absoluta; $\mathrm{FR}=$ frequência relativa; $\mathrm{VC}=$ valor de cobertura .

\begin{tabular}{|c|c|c|c|c|c|c|c|c|c|}
\hline Nome cientifico & $\mathrm{N}^{\circ}$ Parc. & DoA & DoR & DA & $\mathrm{DR}$ & FA & FR & $\mathrm{VC}$ & $\mathrm{VI}$ \\
\hline Sebastiana klotzchiana & 7 & 2.58 & 10.25 & 140.00 & 12.03 & 70 & 6.42 & 22.28 & 28.71 \\
\hline Miconia langsdorfii & 6 & 2.08 & 8.26 & 166.67 & 14.33 & 60 & 5.50 & 22.59 & 28.10 \\
\hline Morta & 8 & 2.00 & 7.92 & 96.67 & 8.31 & 80 & 7.34 & 16.23 & 23.57 \\
\hline Gallesia integrifolia & 4 & 2.79 & 11.05 & 63.33 & 5.44 & 40 & 3.67 & 16.50 & 20.17 \\
\hline Alchornea grandulosa & 7 & 2.08 & 8.25 & 43.33 & 3.72 & 70 & 6.42 & 11.97 & 18.39 \\
\hline Eugenia $\mathrm{sp}$ & 6 & 0.52 & 2.07 & 120.00 & 10.32 & 60 & 5.50 & 12.38 & 17.89 \\
\hline Inga vera & 3 & 1.83 & 7.28 & 46.67 & 4.01 & 30 & 2.75 & 11.29 & 14.04 \\
\hline Cyclolobium vecchi & 3 & 1.49 & 5.91 & 53.33 & 4.58 & 30 & 2.75 & 10.49 & 13.24 \\
\hline Guarea guidonea & 5 & 0.67 & 2.65 & 66.67 & 5.73 & 50 & 4.59 & 8.38 & 12.97 \\
\hline Casearia sylvestris & 5 & 0.65 & 2.56 & 43.33 & 3.72 & 50 & 4.59 & 6.28 & 10.87 \\
\hline Nectandra megapotamica & 3 & 1.03 & 4.10 & 20.00 & 1.72 & 30 & 2.75 & 5.82 & 8.57 \\
\hline Duguetia lanceolata & 3 & 0.78 & 3.07 & 30.00 & 2.58 & 30 & 2.75 & 5.65 & 8.41 \\
\hline Ocotea sp. & 2 & 0.78 & 3.08 & 23.33 & 2.01 & 20 & 1.83 & 5.08 & 6.92 \\
\hline Enterolobium contortisiliquum & 1 & 1.36 & 5.40 & 3.33 & 0.29 & 10 & 0.92 & 5.68 & 6.60 \\
\hline Nectandra oppositifolia & 2 & 0.89 & 3.52 & 13.33 & 1.15 & 20 & 1.83 & 4.67 & 6.50 \\
\hline Eugenia florida & 4 & 0.19 & 0.77 & 23.33 & 2.01 & 40 & 3.67 & 2.77 & 6.44 \\
\hline Luehea divaricata. & 2 & 0.53 & 2.12 & 13.33 & 1.15 & 20 & 1.83 & 3.26 & 5.10 \\
\hline Copaifera langsdorfii & 2 & 0.57 & 2.25 & 10.00 & 0.86 & 20 & 1.83 & 3.11 & 4.95 \\
\hline Euphorbiaceae 1 & 2 & 0.48 & 1.90 & 13.33 & 1.15 & 20 & 1.83 & 3.05 & 4.88 \\
\hline Genipa americana & 3 & 0.14 & 0.57 & 10.00 & 0.86 & 30 & 2.75 & 1.43 & 4.18 \\
\hline Pera glabrata. & 1 & 0.16 & 0.62 & 20.00 & 1.72 & 10 & 0.92 & 2.34 & 3.26 \\
\hline Euterpe edulis & 2 & 0.18 & 0.69 & 6.67 & 0.57 & 20 & 1.83 & 1.27 & 3.10 \\
\hline Calophyllum brasiliensis & 1 & 0.10 & 0.41 & 16.67 & 1.43 & 10 & 0.92 & 1.84 & 2.76 \\
\hline Trichilia catigua & 2 & 0.04 & 0.14 & 6.67 & 0.57 & 20 & 1.83 & 0.71 & 2.55 \\
\hline Machaerium brasiliensis & 2 & 0.02 & 0.10 & 6.67 & 0.57 & 20 & 1.83 & 0.67 & 2.51 \\
\hline Desconhecida & 2 & 0.02 & 0.09 & 6.67 & 0.57 & 20 & 1.83 & 0.66 & 2.50 \\
\hline Eugenia hyemalis & 1 & 0.04 & 0.18 & 13.33 & 1.15 & 10 & 0.92 & 1.32 & 2.24 \\
\hline Anadenanthera colubrina & 1 & 0.24 & 0.96 & 3.33 & 0.29 & 10 & 0.92 & 1.25 & 2.16 \\
\hline Matayba juglandifolia & 1 & 0.09 & 0.36 & 10.00 & 0.86 & 10 & 0.92 & 1.22 & 2.14 \\
\hline Matayba elaegnoides & 1 & 0.14 & 0.56 & 6.67 & 0.57 & 10 & 0.92 & 1.13 & 2.05 \\
\hline Desconhecida 1 & 1 & 0.14 & 0.54 & 6.67 & 0.57 & 10 & 0.92 & 1.11 & 2.03 \\
\hline Croton floribundus & 1 & 0.15 & 0.59 & 3.33 & 0.29 & 10 & 0.92 & 0.88 & 1.80 \\
\hline Cariniana legalis & 1 & 0.03 & 0.13 & 6.67 & 0.57 & 10 & 0.92 & 0.70 & 1.62 \\
\hline Eugenia glazioviana & 1 & 0.02 & 0.09 & 6.67 & 0.57 & 10 & 0.92 & 0.67 & 1.58 \\
\hline Andira fraxinifolia & 1 & 0.02 & 0.09 & 6.67 & 0.57 & 10 & 0.92 & 0.66 & 1.58 \\
\hline Syagrus romanzoffiana. & 1 & 0.08 & 0.31 & 3.33 & 0.29 & 10 & 0.92 & 0.59 & 1.51 \\
\hline Cupania vernalis & 1 & 0.07 & 0.27 & 3.33 & 0.29 & 10 & 0.92 & 0.55 & 1.47 \\
\hline Savia dictyocarpa & 1 & 0.05 & 0.19 & 3.33 & 0.29 & 10 & 0.92 & 0.47 & 1.39 \\
\hline Sorocea bonplandii. & 1 & 0.03 & 0.10 & 3.33 & 0.29 & 10 & 0.92 & 0.39 & 1.31 \\
\hline
\end{tabular}


Terminalia trifolia

Calyptranthes concinna

Desconhecida 2

\begin{tabular}{lllllllll}
1 & 0.02 & 0.07 & 3.33 & 0.29 & 10 & 0.92 & 0.35 & 1.27 \\
1 & 0.02 & 0.06 & 3.33 & 0.29 & 10 & 0.92 & 0.35 & 1.26 \\
1 & 0.01 & 0.04 & 3.33 & 0.29 & 10 & 0.92 & 0.33 & 1.25 \\
1 & 0.01 & 0.03 & 3.33 & 0.29 & 10 & 0.92 & 0.32 & 1.23 \\
\hline
\end{tabular}

Tapirira guianensis 
APÊNDICE 2 Parâmetros fitossociológicos das famílias presentes na mata ciliar da Estação Ecológica de Mogi Guaçú, Mogi Guaçú - SP.,em ordem decrescente de $\mathrm{VI}=$ de valor de importância; DoA = dominância absoluta; DoR = dominância relativa; $\mathrm{DA}=$ densidade absoluta; $\mathrm{DR}$ $=$ densidade relativa; $\mathrm{FA}=$ frequência absoluta; $\mathrm{FR}=$ frequência relativa; $\mathrm{VC}=$ valor de cobertura.

\begin{tabular}{lcccccccc}
\hline & DoA & DoR & DA & DR & FA & FR & VC & VI \\
\hline Euphorbiaceae & 5.60 & 22.22 & 233.33 & 20.06 & 90 & 10.47 & 42.28 & 52.74 \\
Melastomataceae & 2.08 & 8.26 & 166.67 & 14.33 & 60 & 6.98 & 22.59 & 29.57 \\
Morta & 2.00 & 7.92 & 96.67 & 8.31 & 80 & 9.30 & 16.23 & 25.53 \\
Myrtaceae & 0.75 & 2.99 & 153.33 & 13.18 & 70 & 8.14 & 16.17 & 24.31 \\
Mimosaceae & 3.44 & 13.63 & 53.33 & 4.58 & 50 & 5.81 & 18.22 & 24.03 \\
Lauraceae & 2.70 & 10.70 & 56.67 & 4.87 & 50 & 5.81 & 15.57 & 21.38 \\
Phytolacaceae & 2.79 & 11.05 & 63.33 & 5.44 & 40 & 4.65 & 16.50 & 21.15 \\
Fabaceae & 1.54 & 6.09 & 66.67 & 5.73 & 50 & 5.81 & 11.82 & 17.64 \\
Meliaceae & 0.70 & 2.79 & 73.33 & 6.30 & 50 & 5.81 & 9.10 & 14.91 \\
Flacourtiaceae & 0.65 & 2.56 & 43.33 & 3.72 & 50 & 5.81 & 6.28 & 12.10 \\
Indeterminada & 0.28 & 1.08 & 33.33 & 2.87 & 50 & 5.81 & 3.94 & 9.75 \\
Annonaceae & 0.78 & 3.07 & 30.00 & 2.58 & 30 & 3.49 & 5.65 & 9.14 \\
Sapindaceae & 0.30 & 1.18 & 20.00 & 1.72 & 40 & 4.65 & 2.90 & 7.56 \\
Tiliaceae & 0.53 & 2.12 & 13.33 & 1.15 & 20 & 2.33 & 3.26 & 5.59 \\
Caesalpiniaceae & 0.57 & 2.25 & 10.00 & 0.86 & 20 & 2.33 & 3.11 & 5.44 \\
Arecaceae & 0.25 & 1.00 & 10.00 & 0.86 & 30 & 3.49 & 1.86 & 5.35 \\
Rubiaceae & 0.14 & 0.57 & 10.00 & 0.86 & 30 & 3.49 & 1.43 & 4.92 \\
Myrtacea & 0.04 & 0.18 & 13.33 & 1.15 & 10 & 1.16 & 1.32 & 2.48 \\
Lecythidaceae & 0.03 & 0.13 & 6.67 & 0.57 & 10 & 1.16 & 0.70 & 1.86 \\
Moraceae & 0.03 & 0.10 & 3.33 & 0.29 & 10 & 1.16 & 0.39 & 1.55 \\
Combrelaceae & 0.02 & 0.07 & 3.33 & 0.29 & 10 & 1.16 & 0.35 & 1.52 \\
Anacardiaceae & 0.01 & 0.03 & 3.33 & 0.29 & 10 & 1.16 & 0.32 & 1.48 \\
\hline
\end{tabular}

